\title{
Fulfilling the electricity demand of electric vehicles in the long term future: An evaluation of centralized and decentralized power supply systems
}

\author{
Anne Sjoerd Brouwer ${ }^{*}$, Takeshi Kuramochi ${ }^{1}$, Machteld van den Broek, André Faaij \\ Copernicus Institute, Utrecht University, The Netherlands
}

\section{H I G H L I G H T S}

- We model heat and electricity demand of a neighborhood with electric vehicles.

- Six power supply options are modeled: four CHP plants and two grid scenarios.

- Low-carbon grid electricity scenario shows lowest abatement cost: $60-190 € / \mathrm{tCO}_{2}$.

- CHP plants reduce emissions compared to BAU reference, but are more expensive.

- CHP plant performance is sensitive to heat demand and heat grid and CHP efficiencies.

\section{A R T I C L E I N F O}

\section{Article history:}

Received 7 December 2012

Received in revised form 28 January 2013

Accepted 1 February 2013

Available online 6 March 2013

\section{Keywords:}

Electric vehicle

Combined Heat and Power

System analysis

District heating

Merit order

\begin{abstract}
A B S T R A C T
Electric vehicles (EVs) are currently seen as an option for a more sustainable transportation sector, but it is not yet clear how to supply them with electricity whilst striving for low costs and low $\mathrm{CO}_{2}$ emissions. Renewable sources can supply electricity with low emissions, but their penetration rate is still insufficient to meet current demand, let alone the extra demand of EVs. A promising option is supply by Combined Heat and Power (CHP) plants with high combined efficiencies, but an in-depth evaluation of the benefits of combining of EVs and CHP plants is still missing. Therefore, this study evaluates the performance of four different types of CHP plants to power electric vehicles, as compared to use of electricity from the grid. The performance of CHP plants is simulated using detailed datasets of the composition of a future power system, the demand for household electricity and heat, and technical specifications of CHP plants and electric vehicles. We find that the lowest abatement costs of $60-190 € / \mathrm{tCO}_{2}$ are achieved with grid electricity based on a low-carbon electricity mix compared to a business-as-usual electricity mix with marginal emissions of $450-500 \mathrm{gCO}_{2} / \mathrm{kW} \mathrm{h}$. When electricity is supplied by CHP plants, emissions are -1000 to $400 \mathrm{gCO}_{2} / \mathrm{kW} \mathrm{h}$, and abatement costs are $165-940 € / t \mathrm{CO}_{2}$. We did not observe added benefits of joint implementation of CHP plants and EVs: the timing of CHP electricity supply and EV electricity demand did not match well, and abatement costs were not lowered.
\end{abstract}

(c) 2013 Elsevier Ltd. All rights reserved.

\section{Introduction}

The enormous increase in wealth and prosperity in the second half of the 20th century has led to a rapid growth for transportation services. Second largest after the power generation sector, the

Abbreviations: BEV, Battery Electric Vehicle; CCS, carbon capture and storage; $\mathrm{CHP}$, Combined Heat and Power; EV, electric vehicle; FC, fuel cell; $\mathrm{HH}$, household; IGCC, integrated coal gasification combined cycle; NGC, natural gas combined cycle; O\&M, operation and maintenance; PHEV, Plug-in Hybrid Electric Vehicle; PC, pulverized coal.

* Corresponding author. Address: Heidelberglaan 2, Utrecht, The Netherlands. Tel.: +31302537736.

E-mail address: a.s.brouwer@uu.nl (A.S. Brouwer).

${ }^{1}$ Current address: Institute for Global Environmental Strategies, Kanagawa, Japan. transportation sector emits around one quarter of the total fossil fuel related $\mathrm{CO}_{2}$ emissions in OECD countries [1].

Road transportation is responsible for the largest share of transportation $\mathrm{CO}_{2}$ emissions (and related: fuel demand) compared to transportation by train, plane and boat [1]. Personal transportation by car is the largest emitter with shares of $43 \%$ and $64 \%$ of transportation emissions in the UK and US respectively, which corresponds to $15 \%$ and $18 \%$ of total national $\mathrm{CO}_{2}$ emissions in 2009 $[2,3]$.

\footnotetext{
$218 \%$ includes cars and "light trucks" i.e. SUVs, pickup trucks and light vans, of which a share is being used for personal transport. Excluding light trucks, the emissions make up $10 \%$ of the national $\mathrm{CO}_{2}$ emissions.
} 
Electric vehicles (EVs) may improve the sustainability of road transportation in the future [4], because of two reasons: they require fewer to no oil-products, which reduces the dependency on oil imports. Also, they have a more efficient drive train than conventional cars and they may emit less $\mathrm{CO}_{2}$ per kilometer driven depending on the generation mix of electricity and the efficiency of the EV drivetrain. The well-to-wheel EV emissions range from $0 \mathrm{~g} \mathrm{~km}^{-1}$ when powered by renewable sources to about $70 \mathrm{~g} \mathrm{~km}^{-1}$ for a Plug-in Hybrid Electric Vehicle (PHEV) powered by grid electricity [5] and $250 \mathrm{~g} \mathrm{~km}^{-1}$ for a Battery Electric Vehicle (BEV) with a range of $300 \mathrm{~km}$ that is powered by electricity generated from coal [6]. To compare: the well-to-wheel emissions of a similar reference petrol vehicle are $163 \mathrm{~g} \mathrm{~km}^{-1}$ [5].

At the moment, EVs only represent a marginal share of all cars, but their share is expected to become significant in the long term future. Forecasts predict EV shares between 6\% and 30\% by 2030 [7], where $75 \%$ of these vehicles are projected to be PHEVs $[7,8]$.

A large increase in the number of electric vehicles could introduce new problems. Apart from aspects like the construction of a charging infrastructure and legal as well as privacy issues surrounding coordinated charging of EVs, a key issue is the increase in electricity demand [7]. Electric vehicles will increase electricity demand considerably: a single vehicle can increase the electricity consumption of a household by $50 \%$ [9]. It is not yet clear how this extra demand can be fulfilled at the lowest costs and emissions. Renewable energy sources may be hard to implement more rapidly than already targeted by policies, so increases in power demand may be met with more fossil fuels, which can result in significant indirect $\mathrm{CO}_{2}$ emissions [6].

Combined Heat and Power (CHP), which cogenerates electricity and heat, may be an attractive option to supply electricity to EVs because of its high overall energy efficiency (see Table 5). However, its electricity production pattern is based on heat demand, which can lead to a mismatch between electricity supply and demand.

A number of studies have investigated how the electricity demand of EVs can be fulfilled, each with a specific focus. In one study, it was assumed that only renewable sources are used [10], in others that the capacity factors of power plants will remain the same in the future [11,12], or it was just evaluated how many cars the current grid can support [13]. Another study provides an in depth analysis of the electric vehicles, but combines this with a simplified representation of the electricity sector, which features a single conversion efficiency. [14,15]. Also, many studies evaluate the impact of electric vehicles in the near future, even though forecasts indicate that electric vehicles will only achieve significant penetration levels in the mid to long term future $[11,13]$.

In addition, none of the studies [11-15] included CHP as a potential generation option, even though it is encouraged by different parties $[16,17]$. The prime advantage of CHP installations is their high overall efficiency of $85-90 \%$, as both the generated electricity and heat can be used. Furthermore, synergies may occur between $\mathrm{CHP}$ and EV technologies. Many EV implementation plans suggest that EVs will mainly be charged at home, where there is also a significant heat demand. The nature of EVs electricity demand would allow for more optimal CHP operation, because EVs can have flexible demand patterns and will increase the overall household electricity consumption. The former would improve the match between simultaneous heat and electricity production, while the latter would reduce the amount of surplus generated electricity that is sold to the grid at an uneconomic price.

In fact, the number of studies that consider CHP-generated electricity for EV charging is very limited. Some studies discuss the buffering potential of EV batteries at a national level in combination with intermittent electricity sources, where CHP is mentioned alongside solar photovoltaic (PV) and wind power [18,19]. Other studies look at a local level, where the interactions between EVs and the smart grid of a company are evaluated [20], or how household electricity demand curves are influenced by a CHP and an EV [21].

Therefore, the following two research questions are addressed in this paper. The first evaluates whether the electricity generated by CHPs would be used to supply EVs: How can the increased electricity demand of EVs be fulfilled whilst striving for low costs and low $\mathrm{CO}_{2}$ emissions? The second question serves to assess if EVs and CHPs should be jointly implemented: can synergies be achieved between electric vehicles and CHP installations in the long term future? The focus is on urban areas in the developed world, because these are most suitable for EVs in terms of driving distance and because this is where district CHP installations can be found. Results are presented for 2030, as it is expected that EVs could be a mainstream technology by that time [7].

The approach consists of matching electricity supply curves of CHP installations to the demand curves of the household and the EVs at a 15 min interval, to evaluate the match between supply and demand, and observe whether synergies occur. Cost and emission supply curves of the national electricity grid are included to account for exchanges with the grid.

This study contains an in-depth literature study of future CHP installations and builds on the studies by Van Vliet on EVs [5,7] and Van den Broek et al. on the composition of the electricity sector in the future [22]. As such, it considers temporal dynamics at both a household level and national level, and presents a comprehensive analysis of the effect of combining EVs and CHP.

\section{Model framework}

Electricity supply to households and EVs by generation units are compared at three levels: a national level (centralized power plants), the level of a neighborhood (district $\mathrm{CHP}$ ), and household (micro-CHP) level. Costs and $\mathrm{CO}_{2}$ emissions are calculated for a single household based on techno-economic parameters of electricity generators, seasonal electricity demand curves of households and EVs, and heat demand curves of households. The results are compared to the costs and emissions of two reference cases: one household with an EV, the other with a petrol vehicle. The electricity for both is supplied by a business as usual electricity mix in 2030 as projected with MARKAL [22].

Next, it is studied whether synergies can be observed between CHPs and EVs, which would be expressed as a reduction of abatement costs. To this end, the electricity demand of households is split into the demand for the household minus EV, and the demand of the EVs, where that of the household is fulfilled first. Next, the cost and emissions are calculated and the abatement costs compared to both reference cases.

\subsection{System definition}

The research questions are answered by comparing the costs and $\mathrm{CO}_{2}$ emissions of the different cases, of which the system boundaries are shown in Fig. 1. In the two reference cases, electricity is supplied by the national electricity grid, and heat by a household condensing boiler. The cars are powered by either grid electricity or petrol. The other three types of electricity generation are district CHPs, micro CHPs, and centralized low-carbon electricity generation. For the first research question, demand of the household and EV ("total household") are combined to determine the best way to fulfil this demand. For the second, just the electricity demand of the EV is evaluated. All analyses are performed at the level of a single household. Performance indicators are the costs of electricity generation $\left(€ \mathrm{MW} \mathrm{h}^{-1}\right), \mathrm{CO}_{2}$ emissions $\left(t \mathrm{CO}_{2} \mathrm{MW} \mathrm{h}^{-1}\right)$, 


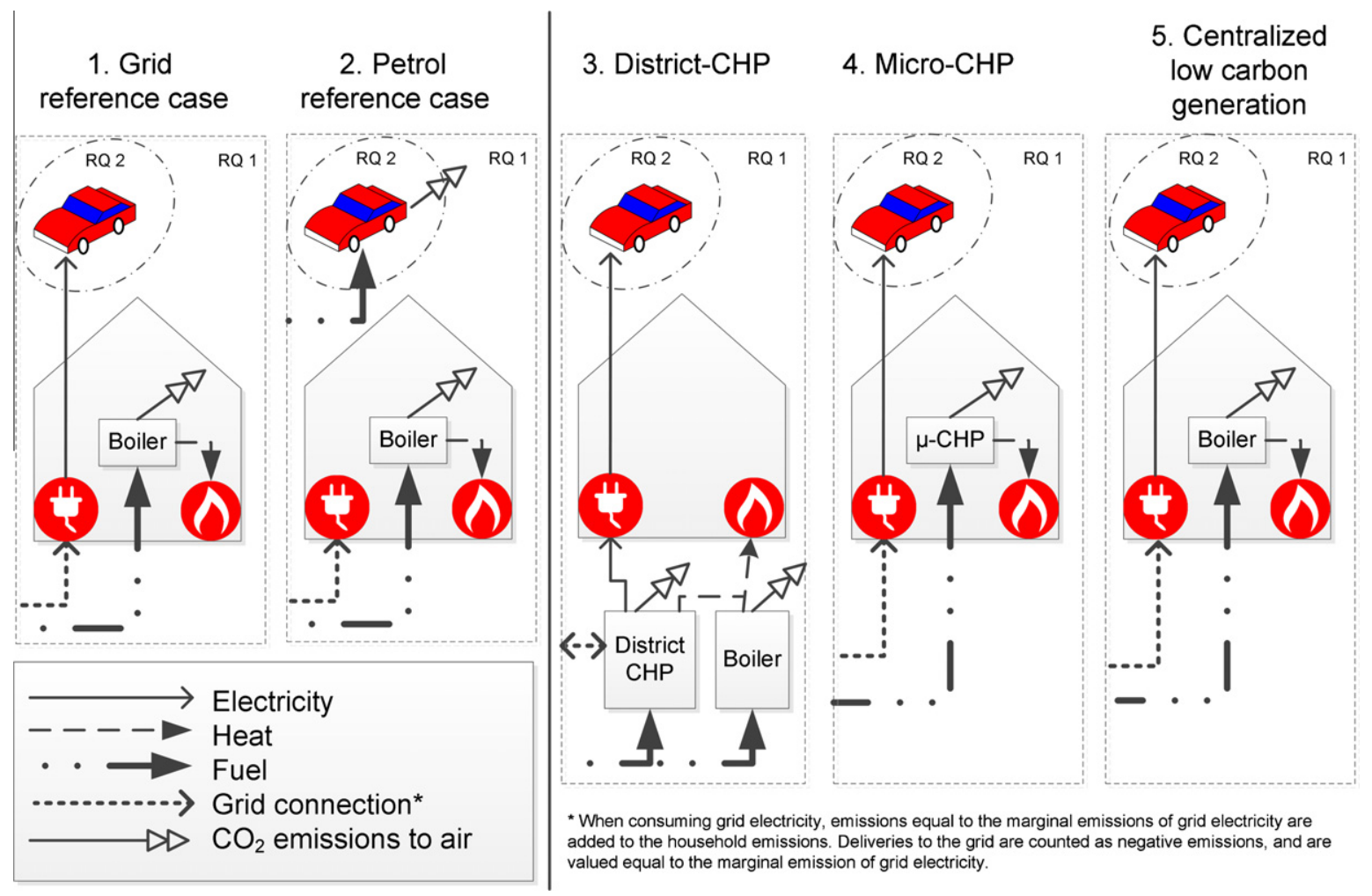

Fig. 1. System boundaries for different power generation types considered for both research questions.

and the abatement costs $\left(€ t \mathrm{CO}_{2}^{-1}\right)$ for either the total household or the EV.

\subsection{Approach overview}

The analysis can be split up into 10 steps (Fig. 2).

Step 1: The first dataset consists of marginal cost and $\mathrm{CO}_{2}$ emission curves of centralized electricity production for three seasons (summer, winter, and spring/autumn) at a 15 min time interval for the year $2030^{3}$ [23]. They were composed by combining prognoses of the Dutch electricity generation system from the MARKAL-NL-UU ${ }^{4}$ model, and forecasts of the national electricity consumption patterns in 2030. Two scenarios were considered: a business as usual (comparable to the Impasse scenario by van den Broek et al. $[22,24])$ for the main analysis, and a scenario with a high share of renewables (comparable to the Grand Coalition scenario) in the sensitivity analysis. For every $15 \mathrm{~min}$ time interval, the most expensive electricity generation unit, the marginal generator, was identified, and its costs and $\mathrm{CO}_{2}$ emissions $(\mathrm{C} \& \mathrm{E})$ were set to be the marginal $\mathrm{C} \& \mathrm{E}$ for that time interval, in the same way as done by Benz et al. [25].

Step 2: Datasets consisting of the electricity consumption patterns of EVs and households minus EV were compiled. The electricity demand pattern of the household minus EV was simulated with the SEPATH generator ${ }^{5}[26,27]$. Two demand patterns for the electricity consumption of electric vehicles (EV) were drafted, namely

\footnotetext{
3 The whole analysis is performed at a 15 min interval for 1 day of each of three seasons: summer, winter as well as spring and autumn combined. This time step is short enough for an accurate analysis [24].

${ }^{4}$ MARKAL-NL-UU is a version of the MARKAL model, originally developed by IEAETSAP specific for the energy sector of the Netherlands. It was developed by van den Broek $[23,25]$.

5 SEPATH is a fully validated pattern generator that simulates the present day electricity demand of households over a 24 -h period. It was developed by KEMA and IVAM $[27,28]$.
}

"controlled" off peak charging and "uncontrolled" charging during peak hours.

Step 3: As it is assumed that the CHP installations follow heat demand, the electricity generation patterns of the CHP installations were deduced from this demand. Heat demand patterns of households were simulated with KEMA's TREIN model ${ }^{6}[28,29]$. Based on the heat-to-power ratio, datasets of the CHP's electricity generation patterns were composed.

Step 4: The gross costs and gross emissions of electricity production by a CHP installation are calculated based on techno-economic specifications with Eqs. (1) and (2). The costs and emissions equivalent to those of a household boiler are allocated to heat production. The CHP is operated based on a heat-led strategy, which is one of the CHP operational strategies suggested by Hawkes and Leach [30]. The other two are an electricity-led and a hybrid strategy that optimizes the total cost. Because the heat-led strategy results in lower costs and emissions, and because the hybrid strategy starts resembling the heat-led strategy at higher reimbursement rates $(>40 \%$ of electricity price), a heat-led strategy is assumed.

Investment costs consist of the CHP investment costs, as well as investments for a heat grid and backup boilers for the district CHP. Furthermore, O\&M costs are added to all of these investments. The costs and emissions per GJ allocated to heat are set equal to those of heat generated by a household boiler [31]. The formulas to calculate the costs and emissions of household boilers and centralized power generation are presented in (Appendix A) [31].

$E C_{\text {gross, household }}=\left(\alpha * I+O M+F-r_{\text {heat }}\right) / n_{\text {households }}$

\footnotetext{
6 TREIN is a bottom-up model developed by KEMA that generates typical heat and electricity demand patterns for 200 households for 6 representative days a year. The heat profiles are based on the physical characteristics of houses and their heating system as well as the behavior of the inhabitants $[29,30]$
} 


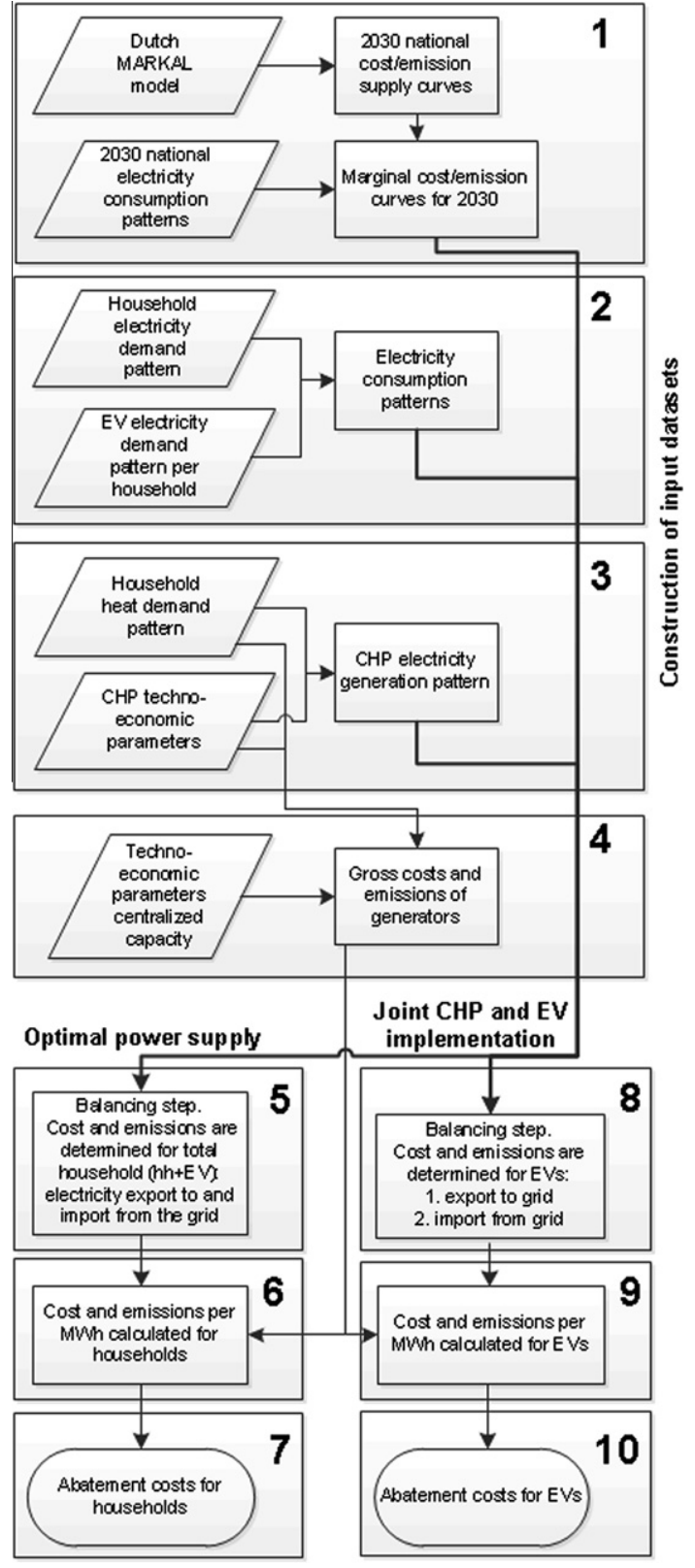

Fig. 2. Schematic overview of modeling approach.

where $E C_{\text {gross,household }}$ is the gross CHP electricity cost for a household ${ }^{7}$ $\left(€ \mathrm{yr}^{-1} \mathrm{hh}^{-1}\right), \alpha$ the capital recovery factor $\left(\mathrm{yr}^{-1}\right), I$ the initial investment $(€), O M$ the annual costs for operation and maintenance $\left(€ \mathrm{yr}^{-1}\right)$, $F$ the annual fuel costs $\left(€ \mathrm{yr}^{-1}\right), r_{\text {heat }}$ the revenues from allocating costs to heat $\left(€ \mathrm{yr}^{-1}\right)$, and $n_{\text {households }}$ is the number of households (hh).

$E E_{\text {gross }, \text { household }}=\left(e_{\text {fuel }}-e b_{\text {heat }}\right) / n_{\text {households }}$

where $E E_{\text {gross,household }}$ is the gross $\mathrm{CO}_{2}$ emissions of electricity for a household $\left(t \mathrm{CO}_{2} \mathrm{yr}^{-1} \mathrm{hh}^{-1}\right), e_{\text {fuel }}$ the annual $\mathrm{CO}_{2}$ emissions from fuel consumption $\left(t \mathrm{CO} 2 \mathrm{yr}^{-1}\right), e b_{\text {heat }}$ the $\mathrm{CO}_{2}$ emission benefits from allocating emissions to heat $\left(t \mathrm{CO} 2 \mathrm{yr}^{-1}\right)$, and $n_{\text {households }}$ is the number of households (hh).

\subsubsection{Calculating the optimal power supply}

Step 5 is a balancing step, where the electricity production of CHP installations is compared to the electricity demand of the total

\footnotetext{
7 "hh" is used as an abbreviation for "household" throughout this article.
}

household for every 15 min interval. When a surplus is generated, electricity is sold to the grid at a percentage of the marginal electricity price (Eq. (3)). The associated emissions from the CHP are allocated to the grid at the marginal emissions of grid electricity (Eq. (4)). The opposite occurs when too little electricity is generated: electricity is bought from the grid, and emissions are allocated to the household. For sales to the grid, the revenues are a fixed percentage of the marginal electricity costs. This reflects that the feed-in of CHP-electricity displaces the fuel costs of centralized generation, but not the investment costs of the centralized power plant.

$E C_{\text {gridbalancing }}=\sum_{i=1}^{96 * 365}\left\{\left(E C_{\text {gridbalancing, } i}\right)\right\}$

$E C_{\text {gridbalancing }}$ is the annual costs of grid electricity for balancing $\left(€ \mathrm{hh}^{-1} \mathrm{yr}^{-1}\right), E C_{\text {gridbalancing, } i}$ the cost of exchanging electricity with the grid at moment $i\left(€ 15 \mathrm{~min}^{-1} \mathrm{hh}^{-1}\right)$.

$E C_{\text {gridbalancing }, i}=\left\{\begin{array}{l}\left(E S_{C H P, i}-E D_{\text {household }, i}\right) * E C_{\text {grid }, i} * p_{\text {costbenefits }} \text { if } E S_{C H P, i}-E D_{\text {household }, i}>0 \\ \left(E S_{C H P, i}-E D_{\text {household }, i}\right) * E C_{\text {grid }, i} \text { if } E S_{C H P, i}-E D_{\text {household }, i} \leq 0\end{array}\right.$

$E C_{\text {gridbalancing, } i}$ is the cost of exchanging electricity with the grid at moment $i\left(€ 15 \mathrm{~min}^{-1} \mathrm{hh}^{-1}\right), E D_{\text {household }}$ the total household electricity demand ( $\mathrm{kWh} 15 \mathrm{~min}^{-1} \mathrm{hh}^{-1}$ ), ES $S_{C H P}$ the CHP electricity supply $\left(\mathrm{kW} \mathrm{h} 15 \mathrm{~min}^{-1} \mathrm{hh}^{-1}\right), E C_{\text {grid }}$ the marginal grid electricity cost, as shown in Fig. 5. $\left(€ \mathrm{~kW} \mathrm{~h}^{-1}\right)$, and $P_{\text {costbenefits }}$ is the reimbursement as a share of the marginal cost (\%).

$E E_{\text {gridbalancing }}=\sum_{i=1}^{96 * 365}\left\{\left(E S_{C H P, i}-E D_{\text {household }, i}\right) * E E_{\text {grid }, i}\right\}$

$E E_{\text {gridbalancing }}$ is the annual emissions of grid electricity $\left(t \mathrm{CO}_{2} \mathrm{yr}^{-1} \mathrm{hh}^{-1}\right), E D_{\text {household }}$ the total household electricity demand $\left(\mathrm{kWh} 15 \mathrm{~min}^{-1} \mathrm{hh}^{-1}\right), \quad E S_{\text {CHP }}$ the CHP electricity supply $\left(\mathrm{kWh} 15 \mathrm{~min}^{-1} \mathrm{hh}^{-1}\right)$, and $E E_{\text {grid }}$ is the marginal grid electricity emissions, as shown in Fig. $6\left(t \mathrm{CO}_{2} \mathrm{~kW} \mathrm{~h}^{-1}\right)$.

Step 6: By correcting the gross costs and emissions of the CHP generation options with the balancing results, the net costs and emissions are calculated (Eqs. (6) and (7)).

$E C_{\text {net }, \text { household }}=\left(E C_{\text {gross, household }}-E C_{\text {gridbalancing }}\right) / E D_{\text {household }}$

$E C_{\text {net,household }}$ is the specific net household electricity costs $\left(€ \mathrm{~kW} \mathrm{~h}^{-1}\right), E C_{\text {gross,household }}$ the electricity costs of total household $\left(€ \mathrm{yr}^{-1} \mathrm{hh}^{-1}\right), E C_{\text {gridbalancing }}$ the total annual costs of grid electricity $\left(€ \mathrm{yr}^{-1} \mathrm{hh}^{-1}\right)$, and $E D_{\text {household }}$ is the electricity demand total household $\left(\mathrm{kW} \mathrm{h} \mathrm{yr}^{-1} \mathrm{hh}^{-1}\right)$.

$E E_{\text {net, household }}=\left(E E_{\text {gross, household }}-E E_{\text {gridbalancing }}\right) / E D_{\text {household }}$

$E E_{\text {net,household }}$ is the specific net total household electricity emissions $\left(t \mathrm{CO}_{2} \mathrm{~kW} \mathrm{~h}^{-1}\right), E E_{\text {gross,household }}$ the electricity emissions of total household $\left(t \mathrm{CO}_{2} \mathrm{yr}^{-1} \mathrm{hh}^{-1}\right), E E_{\text {gridbalancing }}$ the total annual emissions of grid electricity $\left(t \mathrm{CO}_{2} \mathrm{yr}^{-1} \mathrm{hh}^{-1}\right)$, and $E D_{\text {household }}$ is the electricity demand total household ( $\mathrm{kW} \mathrm{h} \mathrm{yr}^{-1} \mathrm{hh}^{-1}$ ).

Step 7: Finally, the abatement costs are calculated as compared to the reference cases using Eq. (8) [32]. The reference cases draw all electricity from the grid, which can be calculated with Eqs. (3) and (4) when assuming a CHP electricity supply of 0 . The costs and emissions of the petrol vehicle in the petrol reference case are those resulting from travelling a distance equivalent to the distance an EV can travel on $1 \mathrm{~kW} \mathrm{h.}{ }^{8}$

\footnotetext{
8 The petrol vehicle is equivalent to the EV in terms of size and performance. Its energy consumption amounts to $1.90 \mathrm{MJ} \mathrm{km}^{-1}$ tank-to-wheel, which corresponds to $\mathrm{CO}_{2}$ emission of $140 \mathrm{~g} \mathrm{~km}^{-1}$ tank-to-wheel $\left(163 \mathrm{~g} \mathrm{~km}^{-1}\right.$ well-to-wheel) [6].
} 


$$
\begin{aligned}
A C_{\text {CO2,gen }}= & \left(E C_{\text {net, }, \text { household,gen }}-E C_{\text {net, household,ref }}\right) /\left(E E_{\text {net, household,ref }}\right. \\
& \left.-E E_{\text {net, household,gen }}\right)
\end{aligned}
$$

where $\mathrm{AC}_{\mathrm{CO} \text {,gen }}$ is the specific $\mathrm{CO}_{2}$ abatement costs of the generator $\left(€ t \mathrm{CO}_{2}^{-1}\right), E C_{\text {net,household,gen }}$ the cost of electricity of the generator ( $€$ $\left.\mathrm{kW} \mathrm{h}^{-1}\right), E C_{\text {net,household,ref }}$ the cost of electricity in the reference case $\left(€ \mathrm{~kW} \mathrm{~h}{ }^{-1}\right), E E_{\text {net,household,ref }}$ the electricity emissions in the reference case $\left(t \mathrm{CO}_{2} \mathrm{~kW} \mathrm{~h}^{-1}\right)$, and $E E_{\text {net,household,gen }}$ is the electricity emissions of the generator $\left(\mathrm{tCO}_{2} \mathrm{~kW} \mathrm{~h}^{-1}\right)$.

\subsubsection{Joint $C H P$ and $E V$ implementation}

The specific costs and emissions of electricity for the EV are composed of two parts: those from CHP electricity and grid electricity. CHP electricity is allocated to either the EV or the household minus EV, where the latter is served first. Any remaining electricity demand is supplied by the electricity grid. From these three elements, the average cost and emissions of CHP electricity is calculated. Those associated with the import of grid electricity for the EV are calculated per time step with the marginal curves from step 2 and added up.

Unlike step 5 , step 8 is a balancing step with separate export and import calculations. First of all, the income from selling surplus CHP-generated electricity to the grid are calculated (Eqs (9) and (10)). As in step 5, cost benefits are a fixed percentage of the marginal electricity costs. The emission that can be allocated to grid electricity are quantified with Eqs. (10) and (11). Next, the costs associated with importing electricity for the EV are calculated with Eqs. (12) and (13). Eq. (13) determines the CHP-generated electricity that is available for the EV after the household minus EV demand has been fulfilled for every time interval. The results are used in Eq. (12) to calculate the costs of buying grid electricity when the CHP supply is insufficient., The emissions of using grid electricity are calculated the same way with the marginal emissions of grid electricity rather than the marginal costs. Lastly, the percentage of electricity supplied by the CHP as part of the total EV demand is determined

$$
E C_{\text {gridbalancing,positive }}=\sum_{i=1}^{96 * 365}\left\{E S_{C H P, \text { togrid }, i} * E C_{\text {grid }, i}\right\}^{*} p_{\text {cos tbenefits }}
$$

$E C_{\text {gridbalancing,positive }}$ is the revenue associated with exporting electricity to the grid $\left(€ \mathrm{yr}^{-1} \mathrm{hh}^{-1}\right), E S_{C H P, \text { togrid, } i}$ the electricity supplied from the CHP to the grid at moment $i\left(\mathrm{kWh} 15 \mathrm{~min}^{-1} \mathrm{hh}^{-1}\right), E C_{\text {grid, } i}$ the marginal cost of grid electricity at moment $i\left(€ \mathrm{~kW} \mathrm{~h}^{-1}\right)$, and $P_{\text {costben- }}$ efits is the reimbursement as a share of the marginal cost (\%).

$E C_{\text {gridbalancing,positive }}=\sum_{i=1}^{96 * 365}\left\{E S_{C H P, \text { togrid }, i} * E C_{\text {grid }, i}\right\} * p_{\text {cos tbenefits }}$

$E C_{\text {gridbalancing,positive }}$ is the revenue associated with exporting electricity to the grid $\left(€ \mathrm{yr}^{-1} \mathrm{hh}^{-1}\right), E S_{C H P, \text { togrid, } i}$ the electricity supplied from the CHP to the grid at moment $i\left(\mathrm{kWh} 15 \mathrm{~min}^{-1} \mathrm{hh}^{-1}\right)$, and $E E_{\text {grid,i }}$ is the emissions of grid electricity at moment $i\left(t \mathrm{CO}_{2} \mathrm{~kW} \mathrm{~h}^{-1}\right)$.

$E S_{\text {CHPtogrid }, i}=\left\{\begin{array}{l}E S_{C H P, i}-E D_{\text {household }, i} \text { if } E S_{C H P, i}-E D_{\text {household }, i}>0 \\ 0 \text { if } E S_{C H P, i}-E D_{\text {household }, i} \leq 0\end{array}\right.$

$E S_{\text {CHPtogrid,i }}$ is the electricity supplied from the CHP to the grid at moment $i\left(\mathrm{~kW} \mathrm{~h} 15 \mathrm{~min}^{-1} \mathrm{hh}^{-1}\right), E S_{C H P, i}$ the electricity supply by $\mathrm{CHP}$ at moment $i$ ( $\mathrm{kWh} 15 \mathrm{~min}^{-1} \mathrm{hh}^{-1}$ ), and $E D_{\text {household, } i}$ is the electricity demand of the total household demand at moment $i$ (kW h $15 \mathrm{~min}^{-1} \mathrm{hh}^{-1}$ ).

$$
E S_{\text {gridtoEV }, i}=\left\{\begin{array}{l}
\left(E D_{E V, i}-E S_{C H P t o E V, i}\right) \quad \text { if }\left(E D_{E V, i}-E S_{C H P t o E V, i}\right)>0 \\
0 \quad \text { if }\left(E D_{E V, i}-E S_{C H P t o E V, i}\right) \leq 0
\end{array}\right.
$$

$E S_{\text {gridtoEV }, i}$ is the grid electricity supplied to EVs at moment $i$ ( $\mathrm{kWh} 15 \mathrm{~min}^{-1} \mathrm{hh}^{-1}$ ), $E D_{E V, i}$ the electricity demand of EV at moment $i\left(\mathrm{~kW} \mathrm{~h} 15 \mathrm{~min}^{-1} \mathrm{hh}^{-1}\right), E S_{C H P t o E V, i}$ is the cHP electricity supply available for EVs at moment $i\left(\mathrm{k} \mathrm{Wh} 15 \mathrm{~min}^{-1} \mathrm{hh}^{-1}\right)$.

$E S_{C H P t o E V, i}=\left\{\begin{array}{l}E S_{C H P, i}-E D_{\text {household }, \text { noEV }, i} \quad \text { ifES } \\ >0 \text { if } E S_{C H P, i}-E D_{\text {household }, \text { noEV }, i} \leq 0\end{array}\right.$

$E S_{C H P t o E V, i}$ is the cHP electricity supply available for EVs at moment $i$ ( $\mathrm{kWh} 15 \mathrm{~min}^{-1} \mathrm{hh}^{-1}$ ), $E S_{\text {CHP, }}$ the electricity supply by CHP at moment $i\left(\mathrm{~kW} \mathrm{~h} 15 \mathrm{~min}^{-1} \mathrm{hh}^{-1}\right.$ ), $E D_{\text {household,noEV }, i}$ the electricity demand of household minus EV demand at moment $i$ ( $\mathrm{kW} \mathrm{h} 15 \mathrm{~min}^{-1} \mathrm{hh}^{-1}$ ).

Step 9: By combining the grid balancing results of step 8 and the gross C\&E figures of step 4, the specific C\&E of electricity to power electric vehicles are calculated with Eqs. (14)-(16).

$p_{\text {CHP }}=\sum_{i=1}^{96 * 365}\left\{E S_{C H P t o E V, i}\right\} / E D_{E V, \text { total }}$

$p_{C H P}$ is the share of EV electricity demand supplied by CHP (\%), $E S_{C H P t o E V, i}$ the local electricity supply available for EVs at moment $i$ ( $\mathrm{kWh} 15 \mathrm{~min}^{-1} \mathrm{hh}^{-1}$ ), and $E D_{E V, \text { total }}$ is the total annual electricity demand of $\mathrm{EV}\left(\mathrm{kW} \mathrm{h} \mathrm{yr}^{-1} \mathrm{hh}^{-1}\right)$.

$$
\begin{aligned}
E C_{E V, \text { spec }}= & \left(E C_{\text {gross, household }}-E C_{\text {gridbalancing,positive }}\right) / E D_{C_{C H} \text { supplied }} \\
& * p_{C H P}+\left(\sum_{i=1}^{96 * 365}\left\{E S_{\text {gridtoEV }, i} * E C_{\text {grid }, i}\right\} / E D_{E V}\right) *\left(1-p_{C H P}\right)
\end{aligned}
$$

$E C_{E V, s p e c}$ is the average cost of electricity for $E V\left(€ \mathrm{~kW} \mathrm{~h}^{-1}\right)$, $E C_{\text {gross, household }}$ the gross $\mathrm{CO}_{2}$ costs of electricity for a household $\left(€ \mathrm{yr}^{-1} \mathrm{hh}^{-1}\right), E C_{\text {gridbalancing,positive the revenue associated with }}$ exporting electricity to the grid $\left(€ \mathrm{yr}^{-1} \mathrm{hh}^{-1}\right), E D_{\text {CHPsupplied }}$ the household electricity demand that is supplied by the CHP $\left(\mathrm{kW} \mathrm{h} \mathrm{yr}^{-1} \mathrm{hh}^{-1}\right), p_{C H P}$ the share of EV electricity demand supplied by $\mathrm{CHP}(\%), E S_{\text {gridtoEV }, i}$ the grid electricity supplied to EVs at moment $i\left(\mathrm{kWh} 15 \mathrm{~min}^{-1} \mathrm{hh}^{-1}\right), E C_{\text {grid, } i}$ the marginal cost of grid electricity at moment $i\left(€ \mathrm{~kW} \mathrm{~h}^{-1}\right)$, and $E D_{E V}$ is the electricity demand of $\mathrm{EV}$ $\left(\mathrm{kW} \mathrm{h} \mathrm{yr}^{-1} \mathrm{hh}^{-1}\right)$

$$
\begin{aligned}
E C_{E V, \text { spec }}= & \left(E C_{\text {gross, household }}-E C_{\text {gridbalancing,positive }}\right) / E D_{C H P_{s} \text { upplied }} * p_{C H P} \\
& +\left(\sum_{i=1}^{96 * 365}\left\{E S_{\text {gridtoEV }, i} E C_{\text {grid }, i}\right\} / E D_{E V}\right) *\left(1-p_{C H P}\right)
\end{aligned}
$$

$E E_{E V \text {,spec }}$ is the average electricity emissions for $\mathrm{EV}\left(t \mathrm{CO}_{2} \mathrm{~kW} \mathrm{~h}^{-1}\right)$, $E E_{\text {gross, household }}$ the gross $\mathrm{CO}_{2}$ emissions of electricity for a household $\left(t \mathrm{CO}_{2} \mathrm{yr}^{-1} \mathrm{hh}^{-1}\right), E E_{\text {gridbalancing,positive }}$ the emissions benefits associated with exporting electricity to the grid $\left(t \mathrm{CO}_{2} \mathrm{yr}^{-1} \mathrm{hh}^{-1}\right), E D_{C H P s u p-}$ plied the household electricity demand that is supplied by the CHP $\left(\mathrm{kW} \mathrm{h} \mathrm{yr}^{-1} \mathrm{hh}^{-1}\right), p_{\mathrm{CHP}}$ the share of EV electricity demand supplied by CHP (\%), ES gridtoEV,i the grid electricity supplied to EVs at moment $i\left(\mathrm{~kW} \mathrm{~h} 15 \mathrm{~min}^{-1} \mathrm{hh}^{-1}\right), E E_{\text {grid, } i}$ the marginal emissions of grid electricity at moment $i\left(t \mathrm{CO}_{2} \mathrm{~kW} \mathrm{~h}^{-1} /\right)$, and $E D_{E V}$ is the electricity demand of EV ( $\left.\mathrm{kW} \mathrm{h} \mathrm{yr} \mathrm{r}^{-1} \mathrm{hh}^{-1}\right)$.

Step 10: The final step consists of calculating the abatement costs as compared to the reference case, which is an EV powered solely by grid electricity, ${ }^{9}$ and as compared to the petrol case (Eq. (17)).

$A C_{\mathrm{CO} 2}=\left(E C_{E V, \text { spec }, \mathrm{CHP}}-E C_{E V, \text { spec }, \text { ref }}\right) /\left(E E_{E V, \text { spec }, \text { ref }}-E E_{E V, \text { spec }, \mathrm{CHP}}\right)$

where $A C_{C O 2}$ is the specific $\mathrm{CO}_{2}$ abatement costs $\left(€ t \mathrm{CO}_{2}^{-1}\right), E C_{E V, \text { spec,- }}$, CHP the cost of electricity for EV for the CHP installation $\left(€ \mathrm{~kW} \mathrm{~h}^{-1}\right)$,

\footnotetext{
${ }^{9}$ The costs and emissions of the reference case for RQ2 are comparable to those calculated for the reference case of RQ1 in step 7. For RQ2, only the electricity demand of the EV is considered, rather than of the total household.
} 
Table 1

Overview of the cases considered in the study.

\begin{tabular}{lll}
\hline System boundaries & Power generation option & $\begin{array}{l}\text { Acronym in } \\
\text { graphs }\end{array}$ \\
\hline $\begin{array}{l}\text { Grid reference } \\
\text { Petrol reference }\end{array}$ & $\begin{array}{l}\text { Grid-ref } \\
\text { Petrol-ref }\end{array}$ \\
District heating & NGCC & NGCC-CHP \\
& Fuel cell & FC-CHP \\
& $\begin{array}{l}\text { Fuel cell with Carbon Capture } \\
\text { and Storage }\end{array}$ & FCCCS-CHP \\
Micro-CHP & Micro CHP & $\mu-C H P$ \\
$\begin{array}{l}\text { Centralized low carbon } \\
\text { generation }\end{array}$ & Low carbon electricity mix & LC-Grid \\
\hline
\end{tabular}

$E C_{E V \text {,spec,ref }}$ the cost of electricity for $\mathrm{EV}$ in the reference case ( $€$ $\left.\mathrm{kW} \mathrm{h}^{-1}\right), E E_{E V \text {,spec,ref }}$ the electricity emissions for $\mathrm{EV}$ in the reference case $\left(t \mathrm{CO}_{2} \mathrm{~kW} \mathrm{~h}^{-1}\right)$, and $E E_{E V, \text { spec,CHP }}$ is the electricity emissions for $\mathrm{EV}$ for the CHP installation $\left(t \mathrm{CO}_{2} \mathrm{~kW} \mathrm{~h}^{-1}\right)$.

\subsection{Cases studied}

A number of different cases are compared to each other in this analysis. The different technologies considered are shown in table 1. At the same time, different EV penetration levels are considered, as the total size of the EV electricity demand affects the outcomes. A $6 \%$ (low penetration), 30\% (high penetration), and 100\% (full penetration) of the cars in a neighborhood are considered. The abatement costs are calculated as compared to the reference case as well as the petrol case.

To determine the optimal power supply, equal shares of controlled and uncontrolled charging are assumed. The share of EV electricity demand is relatively small in this analysis as compared to the household demand, so the impact of the charging pattern is limited. When evaluating the joint implementation of EVs and CHP, the charging patterns are considered separately as they influence the outcomes.

\section{Input data}

\subsection{General assumptions}

In this paper, efficiencies are expressed in lower heating values, costs in $€_{2007}$, and an exchange rate of 0.73 was used to convert $\$_{2007}$ to $€_{2007}$ [33]. Whenever emissions are mentioned, they refer to $\mathrm{CO}_{2}$ emissions. The term EV refers solely to a PHEV, not a BEV.

The analysis is based on costs, so taxes and profits are not taken into account. Also, costs associated with transport of gas and electricity and household connections to their respective grids are not included, because these are considered outside the scope of the study. ${ }^{10}$ The fuel costs and emissions factors used are shown in Table 2.

\subsubsection{Electricity grid losses}

When electricity is transported, losses proportional to the transportation distance are introduced. Average losses in The Netherlands on high, medium and low voltage grids are estimated at $0.6 \%, 3.0 \%$ and $0.4 \%$ respectively [38]. Thus, total distribution losses from a centralized power plant to a household amount to $4 \%$ in total $[39,40]$.

\footnotetext{
10 The costs of transportation of electricity and natural gas that are (indirectly) incurred to households can be based on the capacity of the connection, the quantity of transported energy and/or the ratio of peak demand compared to average demand. These factors are dependent on the physical and legal setup of the system, which have not been further investigated.
}

Table 2

Energy prices and emissions.

\begin{tabular}{llll}
\hline Parameter & Value & Range & Source \\
\hline 2030 cost of coal & $2.7 € \mathrm{GJ}^{-1}$ & $\pm 50 \%$ & {$[34]$} \\
2030 cost of natural gas & $8.5 € \mathrm{GJ}^{-1}$ & $\pm 50 \%$ & {$[34]$} \\
2030 cost of petrol & $0.56 € \mathrm{I}^{-1}$ & $\pm 50 \%$ & {$[34,35]$} \\
$2030 \mathrm{CO}_{2}$ permit price & $15 € t \mathrm{CO}_{2}^{-1}$ & $0-50 € t \mathrm{CO}_{2}^{-1}$ & \\
Coal emission factor & $95 \mathrm{~kg} \mathrm{CO}_{2} \mathrm{GJ}^{-1}$ & & {$[36]$} \\
Natural gas emission factor & $56 \mathrm{~kg} \mathrm{CO}_{2} \mathrm{GJ}^{-1}$ & & {$[36]$} \\
\hline
\end{tabular}

a Based on an forecasted petrol price in the US in 2030 of $30.32 \$(2009)$ $\mathrm{MMBTU}^{-1}$, where the cost part is assumed to consists of $80 \%$ of the price, which was the average share of the oil and refining cost components in 2011 like in July 2011 [37]. This corresponds of an oil price of about $117 \$$ barrel $^{-1}$

\subsection{Electric vehicles and their electricity demand}

A typical average vehicle (a compact 5-seater vehicle equipped with either an electric or petrol drivetrain with a power train of $74 \mathrm{~kW}$ ) is considered in this study based on van Vliet et al. [5] and Campanari et al. [6]. The term 'electric vehicle' refers in this study to a PHEV with an all-electric range of $50 \mathrm{~km}$ (PHEV-50). The specific plug-to-wheel electricity consumption of the EV is $0.103 \mathrm{~kW} \mathrm{~h} \mathrm{~km}^{-1}( \pm 0.02)$ [6]. It is assumed that households will have one car [41,42], and that these cars will drive $38 \mathrm{~km}$ per day, which is the average driving distance in the Netherlands and the United Kingdom $[43,44]$.

The daily electricity demand of EVs is distributed over the day according to two charging regimes: uncontrolled charging, and controlled (off-peak) charging. Uncontrolled charging results in a bell shaped demand curve of which the peak coincides with the evening peak of the regular electricity demand (Fig. 3), as presented in previous studies $[45,46]$. Controlled charging is optimized to fill the nighttime valley in electricity demand.

\subsection{Household heat and electricity demand}

\subsubsection{Household electricity demand}

The electricity demand pattern for a set of 2000 households in a Dutch urban environment in the year 2003 was simulated using the SEPATH generator. Since the generator cannot simulate spring and autumn conditions, the average of the summer and winter simulation were used for these seasons (Fig. 4).

Although the electricity consumption of households has grown strongly in the past, the growth is expected to level off or reverse between 2010 and 2020 [47]. The average household electricity consumption in 2010 of $3400 \mathrm{~kW} \mathrm{~h}$ household ${ }^{-1} \mathrm{yr}^{-1}$ is assumed to stay the same until 2030 ( $\pm 400 \mathrm{~kW} \mathrm{~h}$ ).

\subsubsection{Household heat demand}

The daily heat demand patterns of 12 reference households in a Dutch urban environment were simulated using the TREIN model for 2008. Heat demand is expected to decrease in the future as a result of better insulation [47]. Therefore, the heat demand pattern was uniformly decreased in line with a reduction of the yearly heat demand per average household from $42 \mathrm{GJ}$ in 2000 to $28.1 \mathrm{GJ}$ in 2030 ( $\pm 20 \mathrm{GJ}$ ) (Fig. 5). This amount is composed of $20 \mathrm{GJ}$ for space heating, and $8.1 \mathrm{GJ}$ for hot water heating $[39,47]$. Large variations in heat demand exist between different types of houses, the effect of which is discussed in the sensitivity analysis [26,28].

\subsection{CHP electricity generation}

\subsubsection{District CHP}

Large future district CHP systems ( $>50 \mathrm{MW}$ CHP capacity) are likely to be based on a combined cycle turbine, or SOFC fuel cell. 


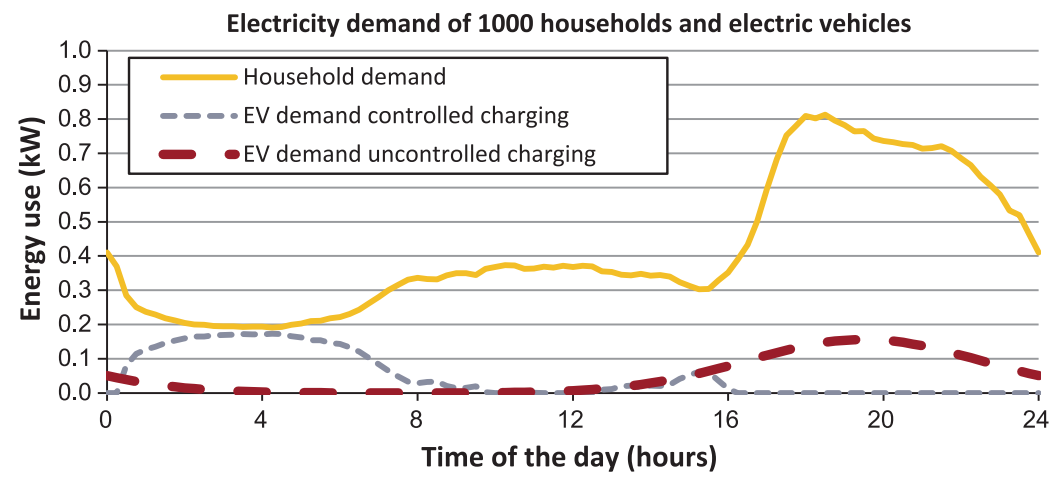

Fig. 3. Charging patterns of electric vehicles and regular electricity demand pattern aggregated for 1000 households on a winterday for high (30\%) EV penetration.

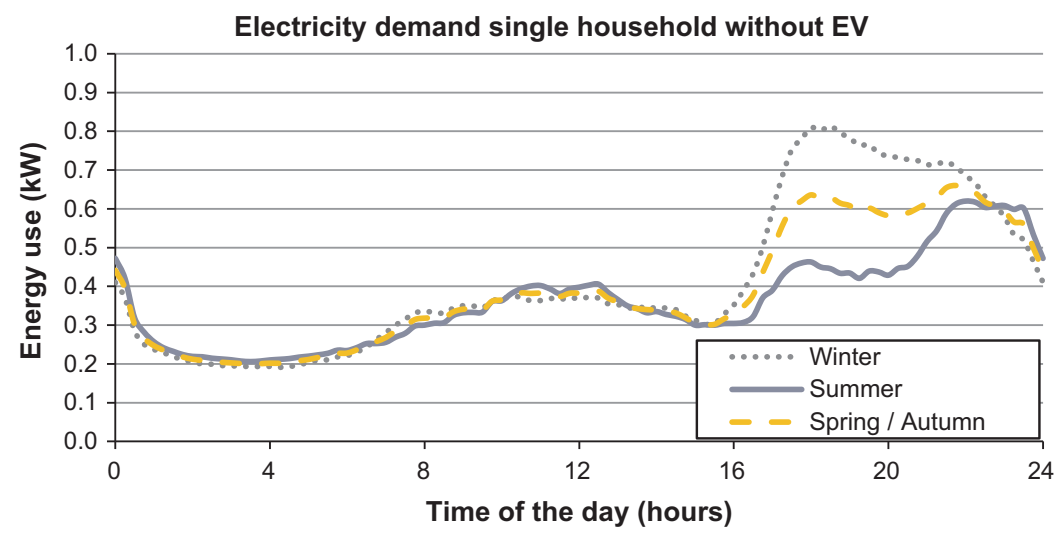

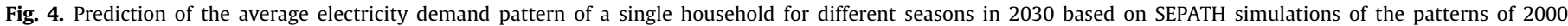
households in 2003.

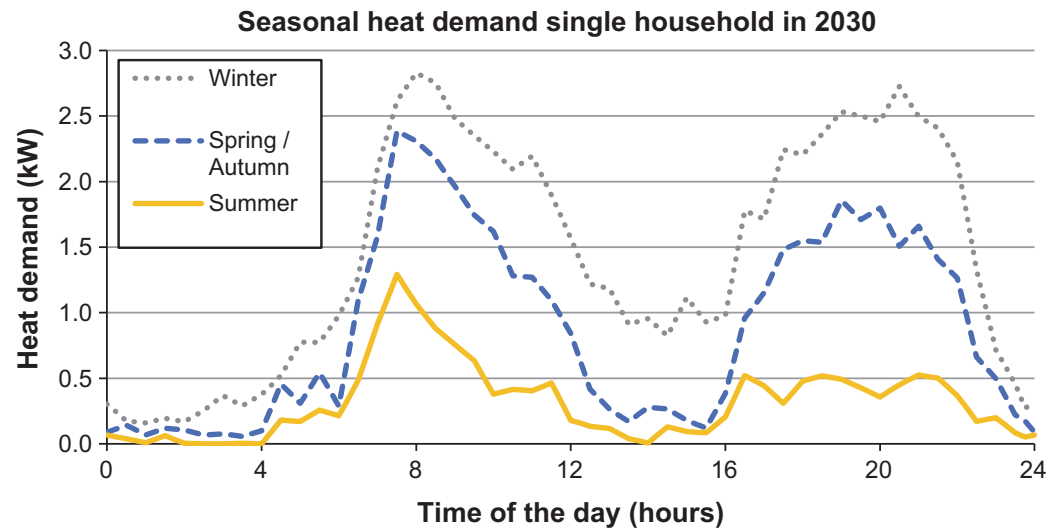

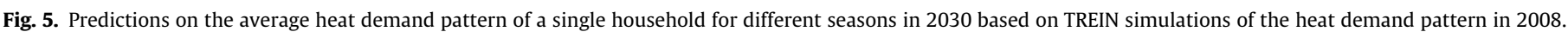

Forecasted efficiencies and investment costs of the different district CHP types were taken from literature, as shown in Table $3 .^{11}$

Table 4 shows other relevant parameters for the district heating system. The available CHP capacity per household is determined in such a way to ensure a high load factor. As a consequence, not all heat demand is covered by the CHP installation, and auxiliary boilers are included to generate heat during peak demand. The heat is transported to households through a heat grid. This grid has two main disadvantages: it is expensive to construct and it introduces heat losses. The cost and losses are rather specific for each area, so

\footnotetext{
$\overline{11}$ A complete overview of reported specifications can be found in Appendix B.
}

an average from different locations is used. Electricity is transported from the district CHP system to the households via the medium and low voltage grids, which also causes transport losses. When the CHP installation produces more electricity than needed in the households, it is exported to the grid at a fixed percentage of the total marginal grid electricity costs, and $100 \%$ of the marginal emissions. If CHP electricity production is insufficient, electricity is imported from the grid at a price equal to the total marginal costs and emissions.

\subsubsection{Micro CHP}

A micro CHP unit is comparable to a regular household boiler, except that it also produces electricity. Compared to the district 
Table 3

Specification of district CHP installations.

\begin{tabular}{|c|c|c|}
\hline NGCC-CHP & 2030 Literature range $[24,48-52]$ & 2030 Model values \\
\hline Electrical efficiency & $35-55 \%$ & $43 \%$ \\
\hline Total efficiency (power and heat) & $60-88 \%$ & $80 \%$ \\
\hline Investment cost $(€ / \mathrm{kW})$ & $€ 773-€ 1250$ & $€ 850$ \\
\hline Scale $\left(\mathrm{MW}_{\mathrm{e}}\right)$ & $30-90$ & 90 \\
\hline O\&M $(€ / M W h) /(\%)^{a}$ & $€ 4.2-€ 11.2$ & $€ 5$ \\
\hline Fuel cell & 2030 Literature range [53-57] & 2030 Model values \\
\hline Electrical efficiency & $30-63 \%$ & $52 \%$ \\
\hline Total efficiency (power and heat) & $65-90 \%$ & $85 \%$ \\
\hline Investment cost $(€ / \mathrm{kW})$ & Target: $€ 1000-€ 1250$ & $€ 1750$ \\
\hline Scale $\left(\mathrm{MW}_{\mathrm{e}}\right)$ & $0.25-5$ & $0.25-5$ \\
\hline O\&M $(€ / M W h) /(\%)^{a}$ & $€ 3-€ 25$ & $€ 15$ \\
\hline Fuel cell + CCS & 2030 Literature range [57-59] & 2030 Model values \\
\hline Electrical efficiency & $40-47 \%$ & $49 \%$ \\
\hline Total efficiency (power \& heat) & $79-82 \%$ & $77 \%$ \\
\hline Investment cost $(€ / \mathrm{kW})$ & Target: $€ 1800-€ 2000$ & $€ 2500$ \\
\hline Scale $\left(\mathrm{MW}_{\mathrm{e}}\right)$ & $0.47-20$ & 20 \\
\hline O\&M $(€ / M W h) /(\%)^{\mathrm{a}}$ & $5 \%$ & $€ 21$ \\
\hline $\mathrm{CO}_{2}$ capture rate & $100 \%$ & $99 \%$ \\
\hline
\end{tabular}

a $\mathrm{O} \& \mathrm{M}$ costs can either be expressed in costs per MW $\mathrm{h}$, or as a yearly percentage of the investment costs.

Table 4

Other relevant parameters district $\mathrm{CHP}$

\begin{tabular}{|c|c|c|}
\hline Parameter & Value & Source \\
\hline Dimension CHP system & 50,000 households ${ }^{a}$ & {$[60]$} \\
\hline Size of CHP system & $1.8 \mathrm{~kW}_{\text {heat }}$ per household ${ }^{\mathrm{b}}$ & [61] \\
\hline Lifetime CHP unit & 25 years & {$[62]$} \\
\hline Electric losses & $3.4 \%^{\mathrm{c}}$ & [38] \\
\hline Revenues from electricity export & $75 \%$ of total marginal $\operatorname{cost}^{\mathrm{d}}$ & \\
\hline Heat losses of district CHP grids & $12.5 \% \mathrm{e}^{\mathrm{e}}$ & [62-64] \\
\hline Investment costs of district CHP grids & $200 M €^{f}$ & {$[62,65,66]$} \\
\hline Lifetime heat grid & $45(40-50)$ years & {$[62,67]$} \\
\hline Backup boiler capacity & $450 \mathrm{MW}$ & [61] \\
\hline Backup boilers investment cost & $5.75 \mathrm{M} €$ (for $450 \mathrm{MW}$ ) & {$[68,69]$} \\
\hline Heat demand covered by backup boilers & $24 \%^{\mathrm{g}}$ & [61] \\
\hline Backup boiler efficiency & $90 \%$ & [62] \\
\hline (Social) discount rate & $5 \%$ & [36] \\
\hline $\mathrm{CO}_{2}$ transport and storage & $16.4 € /$ tonne $^{\mathrm{h}}$ & {$[70,71]$} \\
\hline
\end{tabular}

a This is the size of a large scale district heating system in urban areas in The Netherlands.

b To deliver $28.1 \mathrm{GJ} / \mathrm{hh} / \mathrm{a}$ with a CHP capacity of $1.8 \mathrm{~kW}_{\text {th }}\left(6.5 \mathrm{MJ}_{\mathrm{th}}\right)$ results in about 4330 full load hours. It has been reported that a CHP can be operated economically from 4000 full load hours onwards [61].

c Composed of losses at the medium and low voltage grid.

d When exporting CHP-generated electricity to the grid, centralized production is displaced. This negates fuel and variable O\&M costs at a central level, but not investment costs. The feed-in tariff therefore equals the marginal cost minus the average investment costs, which ranges from $14 \%$ to $44 \%$.

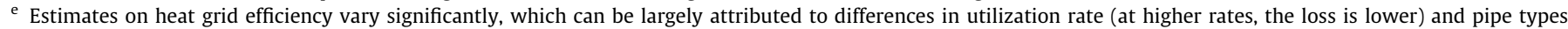

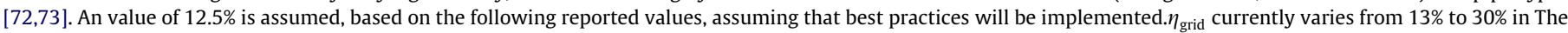

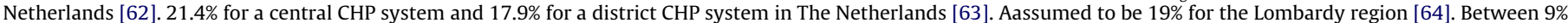
and $16 \%$ for a case study of the city of Pordenone [74]. $\eta_{\text {grid }}$ varies between 6-7\% in Finland, 7-9\% in Sweden and 15-30\% in Russia [72].

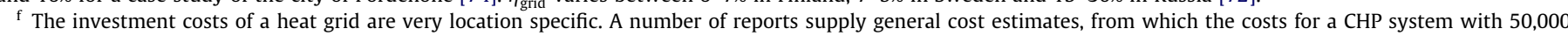

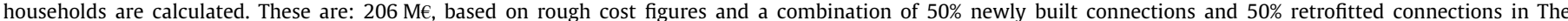

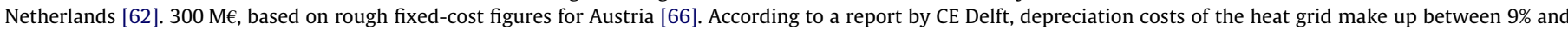

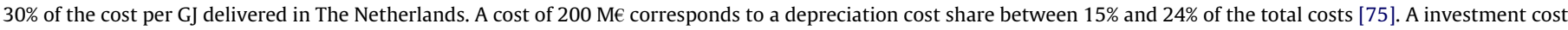
of $200 \mathrm{M} €$ is used, based on the reported values for The Netherlands.

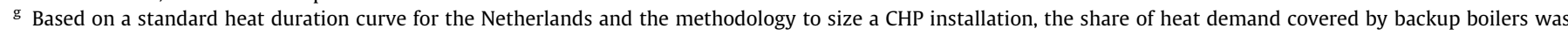
calculated [61].

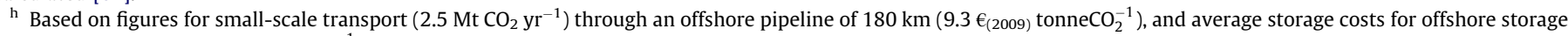
in an depleted gas field $\left(8 €_{(2009)} t \mathrm{CO}_{2}^{-1}\right)$, corrected to $€_{(2007)}[70,71]$.

CHP systems, efficiencies are generally lower and specific investment costs of the installations are higher, but no expensive heat grid is required.

Because of the much smaller scale of micro-CHPs compared to the district CHP systems, the micro-CHP option in this analysis is based on different types of technologies than were chosen for the district CHP systems. Based on the forecasted performance of a Stirling engine micro CHP and a PEMFC fuel cell micro-CHP, a gen- eric "Micro-CHP" option was defined for this study as shown in Table 6.

In Table 5 the other relevant parameters for the micro-CHP case are presented. Similar to the district CHP system, the capacity is insufficient to cover peak heat demand during winter, and a resistive heater will provide heat during these situations. Moreover, electricity import and export prices are the same as for the district-CHP. 
Table 5

Relevant parameters of a micro-CHP system.

\begin{tabular}{lll}
\hline Topic & Value & Source \\
\hline Size $\mu$-CHP & $3 \mathrm{~kW}_{\text {th }}$ per household & \\
Heat supplied by $\mu$-CHP & $90 \%$ of total demand & \\
Discount rate & $10 \%$ & {$[76]$} \\
Lifetime CHP unit & 15 years & {$[77]$} \\
Electric losses & $0.4 \%$ & {$[38]$} \\
Revenues from electricity export & $75 \%$ of total marginal cost & \\
\hline
\end{tabular}

a Size is based on the design criterion of district CHP systems [61]. The size is larger than for a district CHP system, because the relative peak load $\left(\mathrm{kW}_{\mathrm{th}} \mathrm{hh}^{-1}\right)$ is larger. The households in a district CHP system do not have a completely simultaneous heat demand, which results in a flattened peak demand.

b The micro-CHP will not be able to supply all heat, but it will supply significantly more than the district-CHP, as its capacity is $67 \%$ larger. A value of $90 \%$ is therefore assumed.

c Similar to feed-in tariff of a district-CHP.

Table 6

Specification of micro CHP installations for 2030.

\begin{tabular}{|c|c|c|c|}
\hline $\begin{array}{l}\text { Micro-CHP } \\
\text { specifications }\end{array}$ & $\begin{array}{l}\text { Stirling values } \\
{[39,77-79]}\end{array}$ & $\begin{array}{l}\text { PEM-FC values } \\
{[39,53,78]}\end{array}$ & $\begin{array}{l}\text { Model } \\
\text { values }\end{array}$ \\
\hline Electrical efficiency & $16-30 \%$ & $32-36 \%$ & $30 \%$ \\
\hline Total efficiency & $90-94 \%$ & $85-90 \%$ & $90 \%$ \\
\hline $\begin{array}{l}\text { Investment cost }(€ / \\
\quad \mathrm{kW})\end{array}$ & $€ 750-1550$ & $\begin{array}{l}\text { Target: } € 900- \\
€ 1500\end{array}$ & 1400 \\
\hline $\begin{array}{l}\text { O\&M (\% of initial } \\
\text { investment) }\end{array}$ & $3.3 \%^{\mathrm{a}}$ & $2 \%$ & $2 \%$ \\
\hline Scale $\left(\mathrm{kW}_{\mathrm{e}}\right)$ & $1-1500$ & $1-5$ & 1.5 \\
\hline
\end{tabular}

a This percentage seems to be on the high side, because Stirling engines are generally considered low maintenance [80].

Table 7

Relevant parameters of central heating per household.

\begin{tabular}{lll}
\hline Parameter & Value & Source \\
\hline Efficiency & $94.1 \%$ for room heating $79.7 \%$ for hot water & {$[39]$} \\
Investment & $€ 1000$ per household $(10 \mathrm{~kW}$ heater $)(€ 720-$ & {$[62,81]$} \\
$\quad$ cost & $€ 2000)$ & \\
O\&M costs & $€ 15$ per household $\mathrm{yr}^{-1}$ & {$[81]$} \\
Lifetime & $15 \mathrm{yr}$ & {$[82]$} \\
Discount rate & $10 \%$ & {$[36,76]$} \\
\hline
\end{tabular}

Table 8

Other parameters used for calculating costs and emissions centralized power plants.

\begin{tabular}{lll}
\hline Discount rate & $10 \%$ & {$[85]$} \\
Lifetime plants & $\begin{array}{l}20 \text { years for NG plants, 40 year for coal } \\
\text { plants }\end{array}$ & {$[24,85]$} \\
& $85 \%$ & {$[85]$} \\
Capacity factor & $85 \%$ & {$[85]$} \\
$\mathrm{CO}_{2}$ capture ratio CCS & $10.8 € /$ tonne $\mathrm{CO}_{2}$ stored $^{\mathrm{a}}$ & {$[70,71]$} \\
$\mathrm{CO}_{2}$ transport and storage & \\
\multicolumn{1}{c}{ costs } & &
\end{tabular}

a Based on figures for large-scale transport $\left(20 \mathrm{MtCO}_{2} \mathrm{yr}^{-1}\right)$ through an offshore pipeline of $180 \mathrm{~km}\left(3.4 €_{(2009)} / \mathrm{tCO}_{2}\right)[71]$, and average storage costs for offshore storage in an depleted gas field $\left(8 €_{(2009)} t \mathrm{CO}_{2}^{-1}\right)$, corrected for inflation [70,71].

\subsubsection{Household boiler specifications}

A household boiler is used in a number of cases to generate heat. The heat demand and operational parameters of a household boiler are shown in Table 7.

\subsection{Centralized electricity generation}

\subsubsection{Grid electricity}

The 2030 cost and $\mathrm{CO}_{2}$ emissions of grid electricity are assumed to be equal to the variable generation costs and emissions of the marginal electricity generating unit. The expected electricity demand is based on the demand in 2006-2008, which is corrected with an autonomous increase factor of $1 \%$ per year $[47,83,84]$.

The electricity supply curves were constructed based on the expected installed capacities of different power plant types in The Netherlands in 2030 and the techno-economic parameters of these power plants. The capacities were modeled using the MARKAL-NLUU based on the Impasse and Grand Coalition MARKAL-scenarios, as described in $[22,23,25]$, for the reference and low-carbon scenarios respectively. The techno-economic data are based on those of the MARKAL model, and of Table 8 . The merit order is based on the levelized variable costs, and shown together with the production costs and emissions in Table 9.

The supply curves of the business as usual scenario are depicted in Figs. 6 and 7. During the night, the marginal production units are older coal fired power plants (existing super- and subcritical), which have somewhat lower generation costs, but much higher emissions than the more modern natural gas power plants (NGCC plants from 2020 and 2030) that supply electricity during daytime.

The average costs and emissions for an $10 \%$ increase or decrease of the national electricity demand are also included. When electricity demand increases, natural gas capacity will be more often the marginal capacity, leading to lower emissions and somewhat higher prices. A reduced demand leads to a shift to coal generation, with the opposite effect. During the night, more efficient coal units will be used when the demand is lower, which reduces the emissions.

\section{Results}

\subsection{Electricity demand of electric vehicles}

The electricity demand of an EV is $3.9 \mathrm{~kW} \mathrm{~h}( \pm 0.8 \mathrm{~kW} \mathrm{~h})$ per car per day assuming it travels $38 \mathrm{~km}$ per day and has a plug-to-wheel electricity consumption of $0.103 \mathrm{~kW} \mathrm{~h} / \mathrm{km}( \pm 0.22 \mathrm{~kW} \mathrm{~h})$. As shown in Table 10, the extra demand for EVs results in a small to moderate increase in electricity demand at neighborhood level in the low and high EV penetration cases. However, in the full penetration case, the resulting increase of $42 \%$ of normal household electricity demand is considerable. The distribution of the extra demand over the day is important, as shown in Fig. 8. When charging in an uncontrolled way, the extra demand coincides with evening peak demand at household and national level.

\subsection{Electricity production of CHP installations}

The pattern of CHP electricity production over time depends on the pattern of the heat demand and varies throughout the seasons. Fig. 9 shows the excess or lack of electricity generation by the CHP compared to the demand, which needs to be exported or imported to or from the grid, respectively. Remarkably, the electricity production by the CHP coincides better with the EV-demand pattern of uncontrolled charging than controlled charging during the night. The depicted option, a fuel cell with CCS, has the lowest heat-topower ratio, and produces most electricity as a result. Other district CHP installations produce up to $50 \%$ of the EV electricity demand, and a micro CHP installation only $30 \%$.

In Fig. 10, an overview is given of the total yearly average electricity flows per household for different types of CHP installations. Results for controlled and uncontrolled charging resemble each other closely. As shown, a CHP installation with a relative high electricity production (low heat-to-power ratio) does not substantially reduce the amount of electricity that has to be imported. Although it is possible to export almost six times more electricity with a fuel cell with CCS than with the NGCC, the imports are only 
Table 9

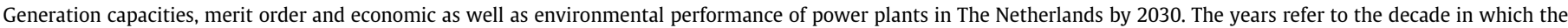
plants were built. Low-carbon capacity is the capacity on which the LC E-mix option is based.

\begin{tabular}{|c|c|c|c|c|c|}
\hline Technology & $\begin{array}{l}\text { Reference business as usual } \\
\text { Capacity (GW) }\end{array}$ & $\begin{array}{l}\text { Variable (O\&M and } \\
\text { fuel)_costs }\left(€ \mathrm{MW} \mathrm{h}^{-1}\right)\end{array}$ & $\begin{array}{l}\text { Total electricity costs of } \\
\text { generator }\left(€ \mathrm{MW} \mathrm{h}^{-1}\right)\end{array}$ & $\begin{array}{l}\text { Emissions of generator } \\
\left(t \mathrm{CO}_{2} \mathrm{MW} \mathrm{h}^{-1}\right)\end{array}$ & $\begin{array}{l}\text { Low-carbon } \\
\text { capacity (GW) }\end{array}$ \\
\hline \multicolumn{6}{|c|}{ Merit order for business as usual scenario (early dispatch $\rightarrow$ late dispatch) } \\
\hline Other & 0.7 & 0.0 & 0.0 & 0.0 & 0.7 \\
\hline Wind offshore & 4.2 & 0.0 & 83.8 & 0.0 & 4.2 \\
\hline Wind onshore & 6.0 & 0.0 & 58.2 & 0.0 & 6.0 \\
\hline Nuclear & 0.5 & 6.9 & 49.4 & 0.0 & 0.5 \\
\hline IGCC with CCS & 0.0 & 32.3 & 70.0 & 0.1 & 6.3 \\
\hline $\begin{array}{l}\text { IGCC retrofitted } \\
\text { with CCS }\end{array}$ & 0.0 & 32.3 & 70.0 & 0.1 & - \\
\hline PC 30 & 2.7 & 33.0 & 60.5 & 0.7 & - \\
\hline PC 20 & 0.2 & 35.1 & 63.8 & 0.7 & - \\
\hline IGCC & 0.3 & 36.5 & 72.7 & 0.8 & 0.3 \\
\hline PC 10 & 3.6 & 37.2 & 68.1 & 0.8 & 3.6 \\
\hline $\begin{array}{l}\text { Existing } \\
\quad \text { supercritical }\end{array}$ & 1.2 & 38.8 & 64.6 & 0.8 & 1.2 \\
\hline PC with CCS & 0.0 & 43.1 & 81.2 & 0.1 & - \\
\hline $\begin{array}{l}\text { PC retrofitted } \\
\text { with CCS }\end{array}$ & 0.0 & 43.1 & 81.2 & 0.1 & 1.8 \\
\hline $\begin{array}{l}\text { Existing } \\
\quad \text { subcritical }\end{array}$ & 2.1 & 43.3 & 69.1 & 0.9 & 2.1 \\
\hline NGCC 30 & 0.6 & 55.8 & 67.0 & 0.3 & 0.6 \\
\hline NGCC 20 & 5.0 & 58.6 & 69.9 & 0.4 & 5.0 \\
\hline NGCC 00 & 3.5 & 60.6 & 73.2 & 0.4 & 3.5 \\
\hline NGCC 10 & 5.9 & 60.6 & 73.2 & 0.4 & 5.9 \\
\hline NGCC with CCS & 0.0 & 64.8 & 82.1 & 0.1 & 2.7 \\
\hline $\begin{array}{l}\text { NGCC retrofitted } \\
\text { with CCS }\end{array}$ & 0.0 & 66.1 & 83.5 & 0.4 & - \\
\hline $\mathrm{CHP}$ CC & 1.8 & 89.3 & 110.1 & 0.5 & 0.8 \\
\hline CHP gas engine & 0.0 & 92.2 & 109.1 & 0.5 & 5.0 \\
\hline CHP GT & 0.0 & 130.4 & 147.7 & 0.8 & 1.1 \\
\hline
\end{tabular}

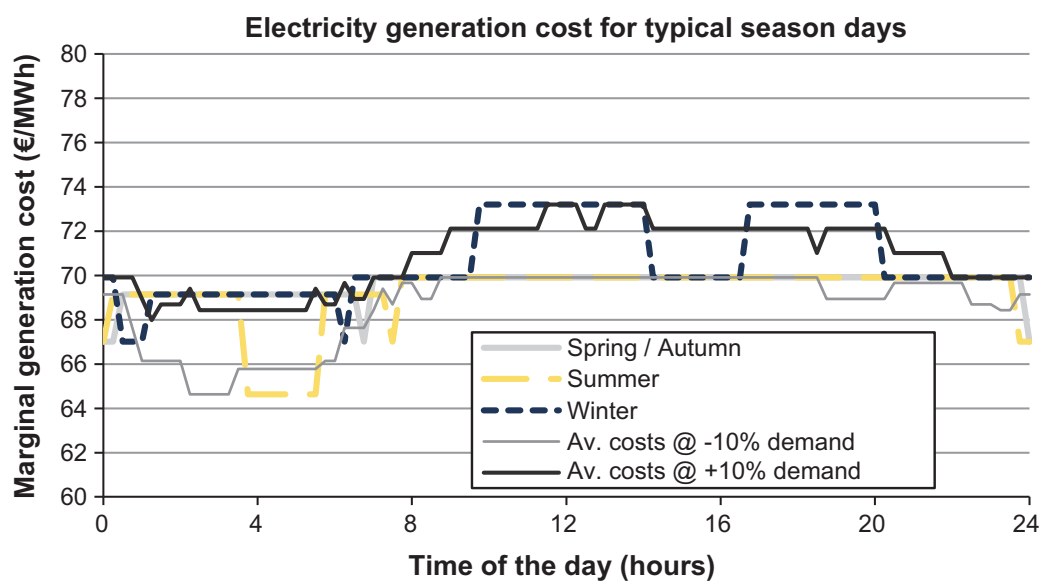

Fig. 6. Total marginal grid electricity generation cost throughout the day in The Netherland in 2030 in the Business as Usual scenario.

Electricity emissions for typical season days

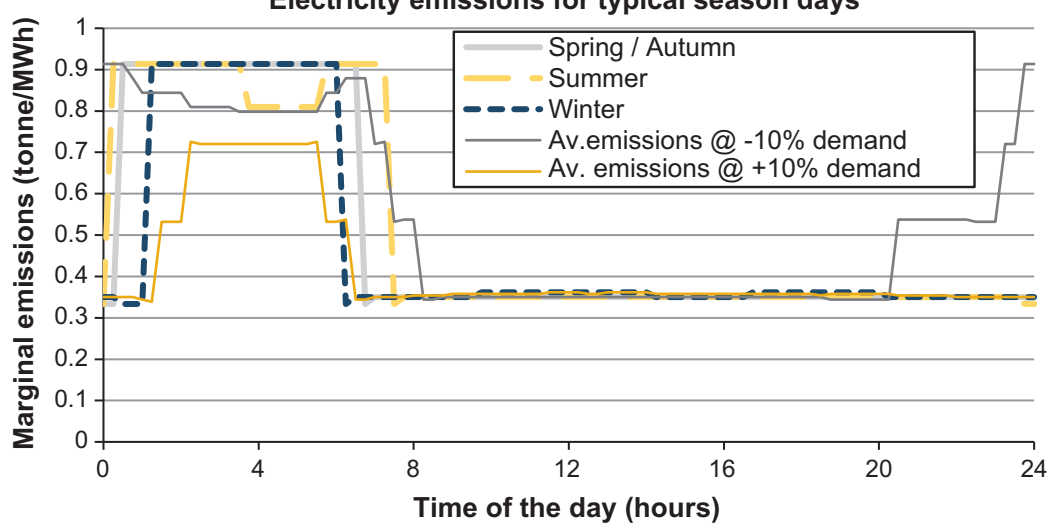

Fig. 7. Marginal emissions of grid electricity throughout the day in The Netherland in 2030 in the Business as Usual scenario. 
$25-35 \%$ lower. This is because electricity generation is much larger than supply most of the time: only during hours when heat demand is low, the deficit of electricity generation has to be imported. Finally, in a case with full EV-penetration and supply of electricity by a micro-CHP, which a type of CHP with high heatto-power ratio, the export volume is very small and the import volume is large.

Table 10

Average annual EV electricity demand on a household level.

\begin{tabular}{|c|c|c|}
\hline & 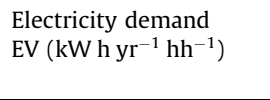 & $\begin{array}{l}\text { \% Increase of } \\
\text { neighborhood } \\
\text { demand }\end{array}$ \\
\hline Low EV penetration (6\%) & $86 \mathrm{~kW} \mathrm{~h}( \pm 19 \mathrm{~kW} \mathrm{~h})$ & $2.5 \%$ ( $\pm 0.5 \%$-point $)$ \\
\hline High EV penetration (30\%) & $429 \mathrm{~kW} \mathrm{~h}( \pm 93 \mathrm{~kW} \mathrm{~h})$ & $12.6 \%( \pm 2.7 \%$-point $)$ \\
\hline Full EV penetration (100\%) & $1429 \mathrm{~kW} \mathrm{~h}( \pm 309 \mathrm{~kW} \mathrm{~h})$ & $42.0 \%$ ( $\pm 9.1 \%$-point $)$ \\
\hline
\end{tabular}

\subsubsection{Optimal way to supply electricity to household and EV}

Large differences occur between the specific emissions of different generation options (Fig. 11). The FCCCS-CHP achieves negative emissions on paper, because emissions that are allocated to heat $\left(1.8 t \mathrm{CO}_{2} \mathrm{hh}^{-1} \mathrm{yr}^{-1}\right)$ are subtracted from the already low emissions. A slight increase can be seen for all CHP options from 30\% to $100 \%$ penetration, which is the result of insufficient electricity production by the CHP installation, mostly during the night. Instead, mainly coal-fired grid electricity is used at these times, with high associated emissions. The emissions of a household with a petrol vehicle are over twice as large as the emissions of any CHP plant or the low carbon grid scenario.

The cost figures show that district CHP generators are more expensive than the others (Fig. 12). This can be explained by the expensive installation, which consists of relatively expensive CHP-unit, and extra costs for the heat grid. The micro-CHP lacks the heat grid and backup boilers, and is much cheaper. The same applies for the grid reference and low carbon electricity mix, which is powered by centralized power plants. The penetration level has a

Total electricity demand of a single household for different EV charging patterns and penetration levels

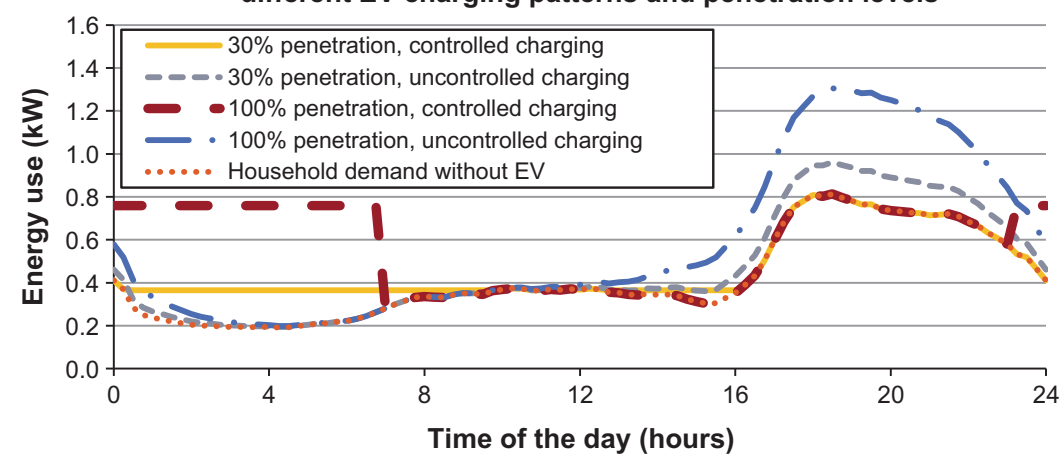

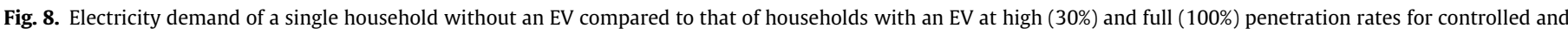
uncontrolled charging patterns.
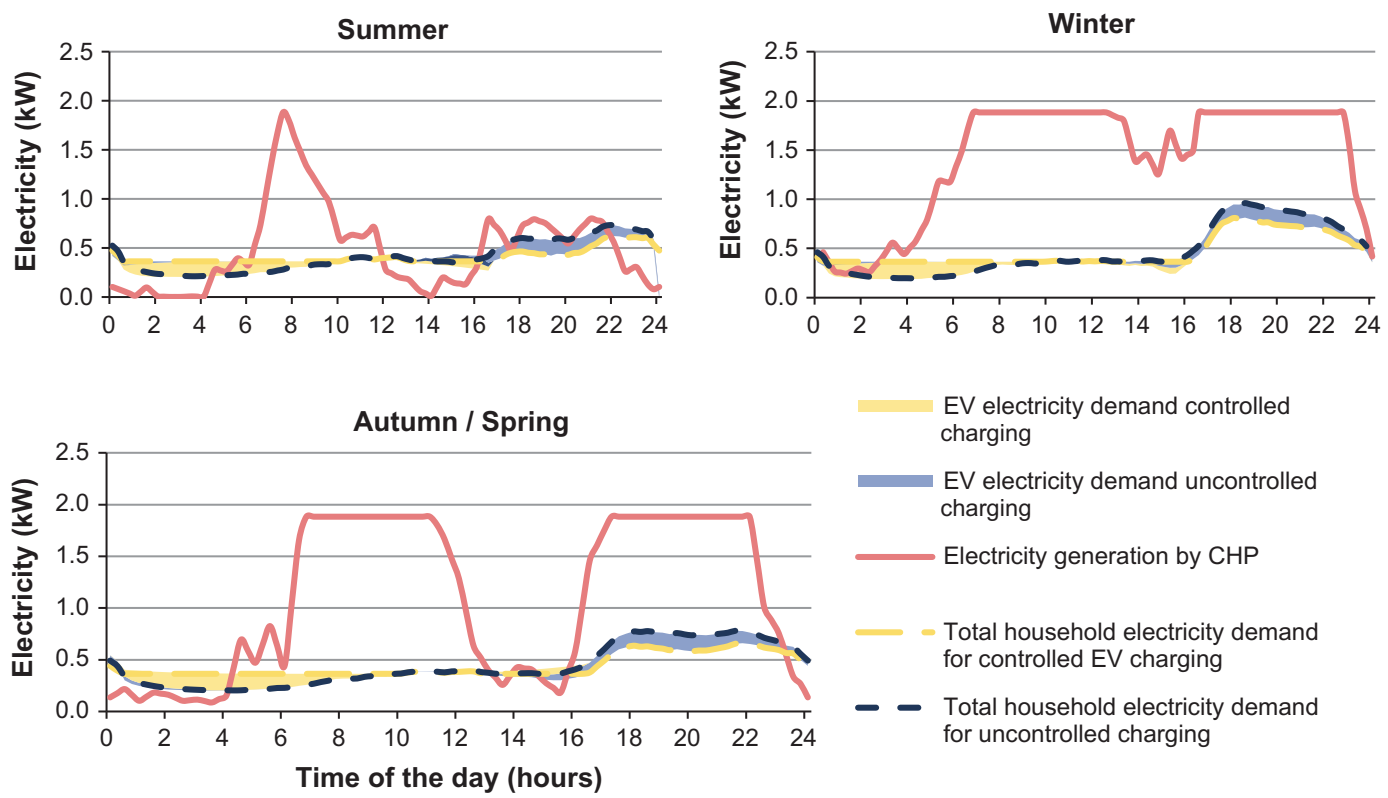

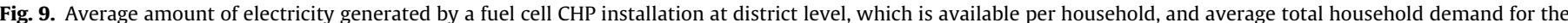

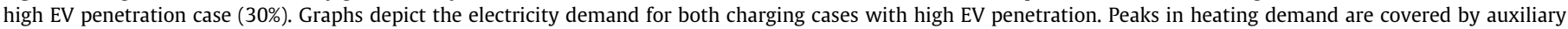
boilers, so electricity generation by the CHP is stable during peak hours. 


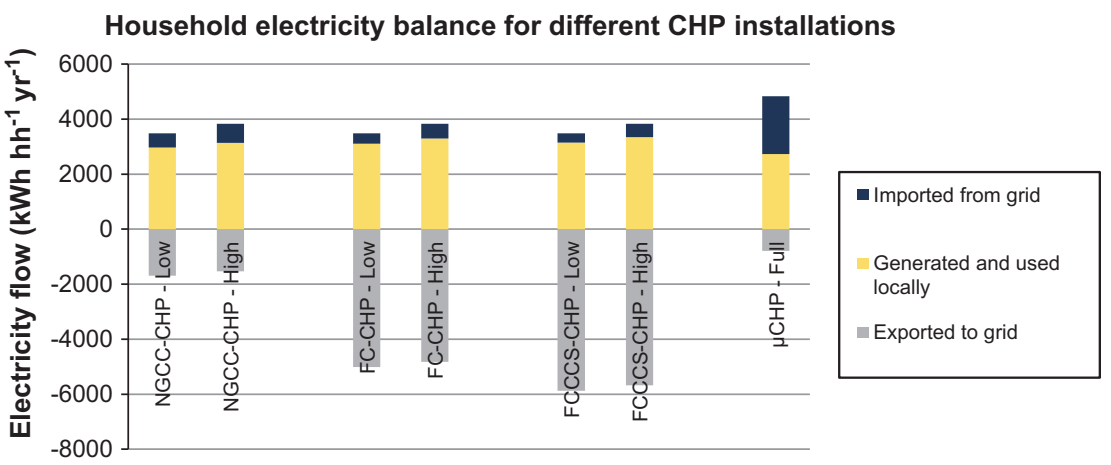

Fig. 10. Electricity balances for the controlled charging cases at low (6\%) and high (30\%) EV penetration levels over the course of one year.

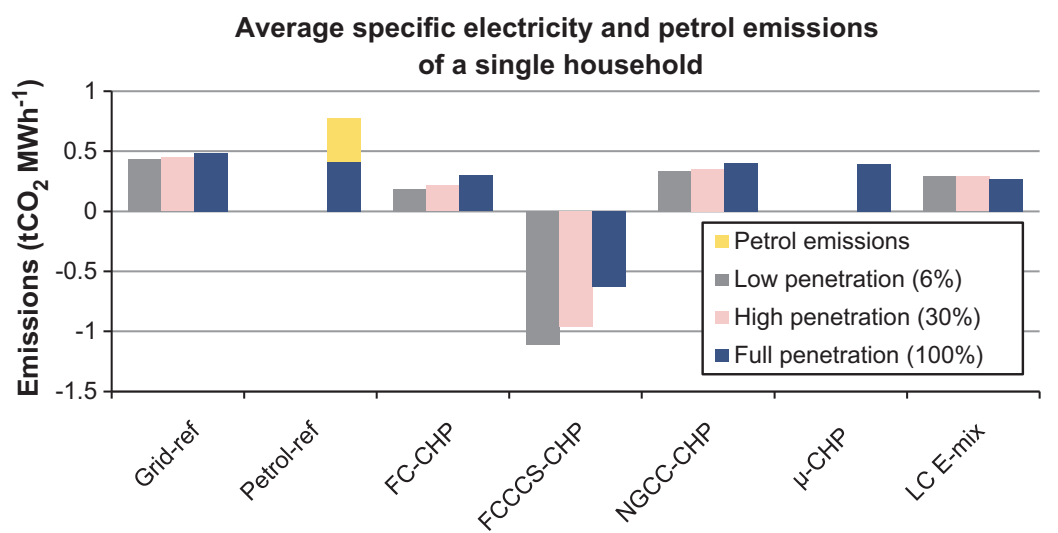

Fig. 11. Specific emissions of the different cases. Petrol vehicle emissions are emitted whilst driving the average driving distance (38 $\mathrm{km} \mathrm{day}^{-1}$ ).

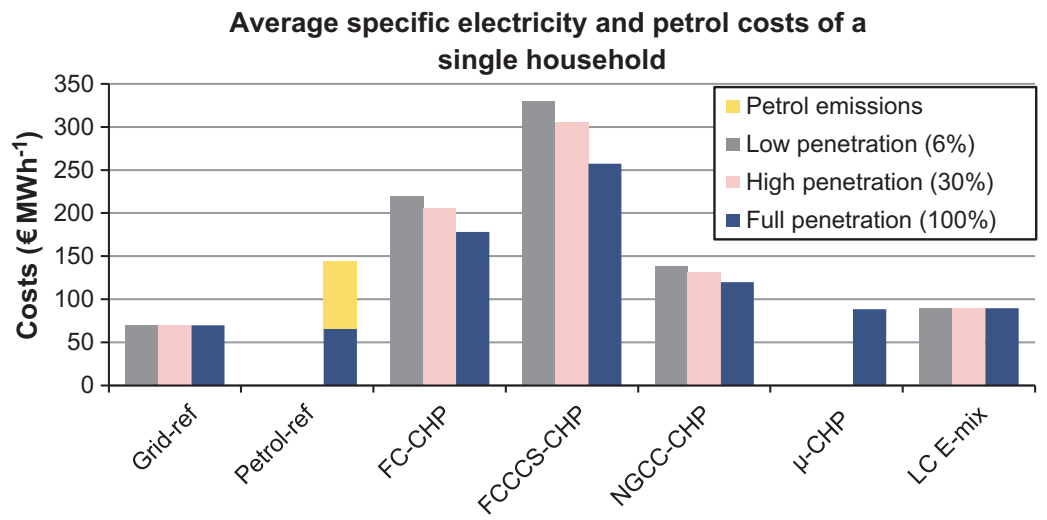

Fig. 12. Average electricity costs of households in the different cases. Petrol vehicle emissions are emitted whilst driving the average driving distance $\left(38 \mathrm{~km}^{-1}{ }^{-1}\right)$.

minimal effect on the specific electricity cost for the grid powered cases, because the electricity price does not fluctuate much during the day, as shown in Fig. 6.

Abatement costs of CHP options are relatively high as compared to the grid reference situation (Fig. 13). The main reason is the high costs of these options, and the relatively small reduction in emissions. Centralized options have relatively low abatement costs, especially those with CCS, as a result of the low emissions.

Abatement costs are higher for uncontrolled charging than controlled charging. This is caused by the relative low emissions in the uncontrolled grid reference case, to which the CHP options compare relatively unfavorably.

All cases can power a household and a vehicle with lower emissions than the petrol vehicle reference case (Fig. 14). The differences in abatement costs are mainly caused by the costs of the different cases. The grid-powered and micro-CHP cases are relatively cheap and can achieve negative abatement costs. It must be noted that this only includes the energy that is required to drive a car, which is only a minor component of the total cost of ownership. Energy costs make up only $2-4 \%$ of the total cost of ownership for EVs [5]. This topic is further discussed in the discussion section.

\subsubsection{Joint CHP and EV implementation}

After household demand has been fulfilled, EVs are charged with CHP-generated electricity. The extent to which electricity is available for EV charging is depicted in Fig. 15. Two trends can be distinguished for district CHP installations: more CHP-generated electricity is used for charging at higher penetration levels 


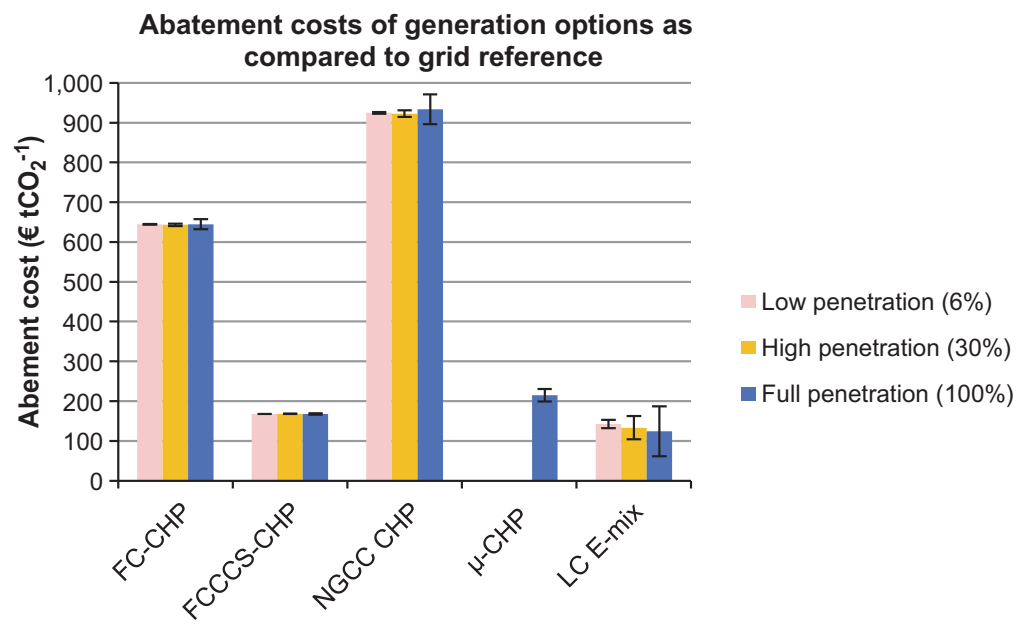

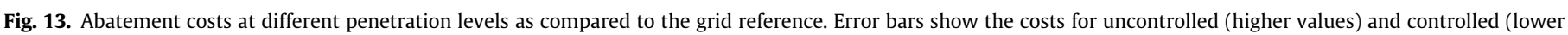
values) charging

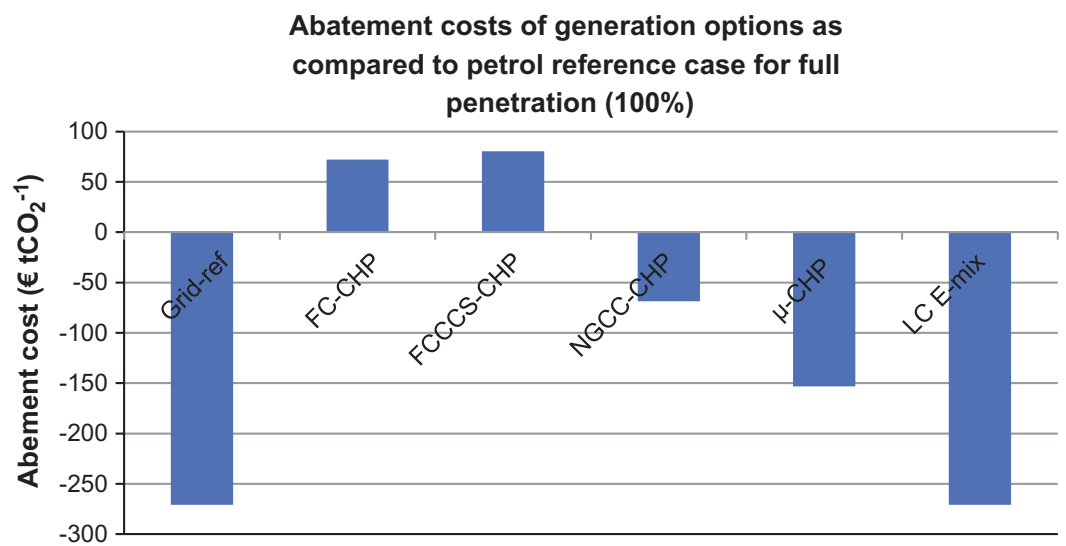

Fig. 14. Abatement costs for different penetration levels as compared to petrol reference case at full (100\%) penetration.

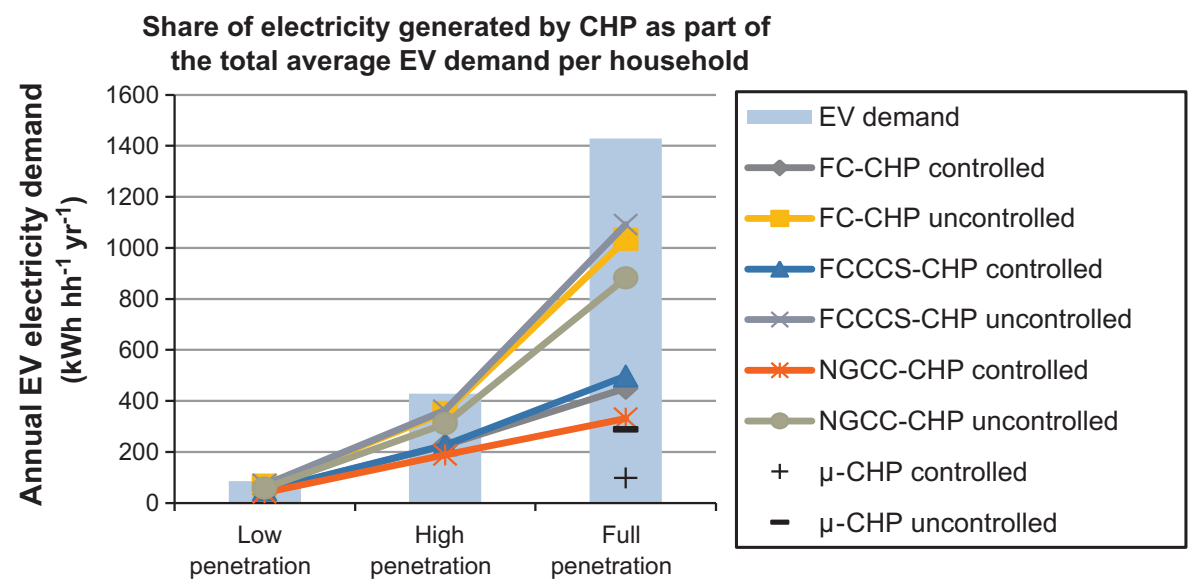

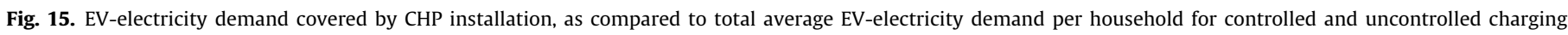
modes.

and a clear difference exists between controlled and uncontrolled charging. The latter is the result of the match between CHP-electricity generation and EV demand. While the EV-demand of the uncontrolled charging coincides with the evening peak of CHP- electricity production, the controlled charging takes place when electricity production is low. As a result, $25-35 \%$ of the electricity for controlled charging is supplied by a CHP at full penetration, compared to $60-75 \%$ for uncontrolled charging. Micro-CHP elec- 


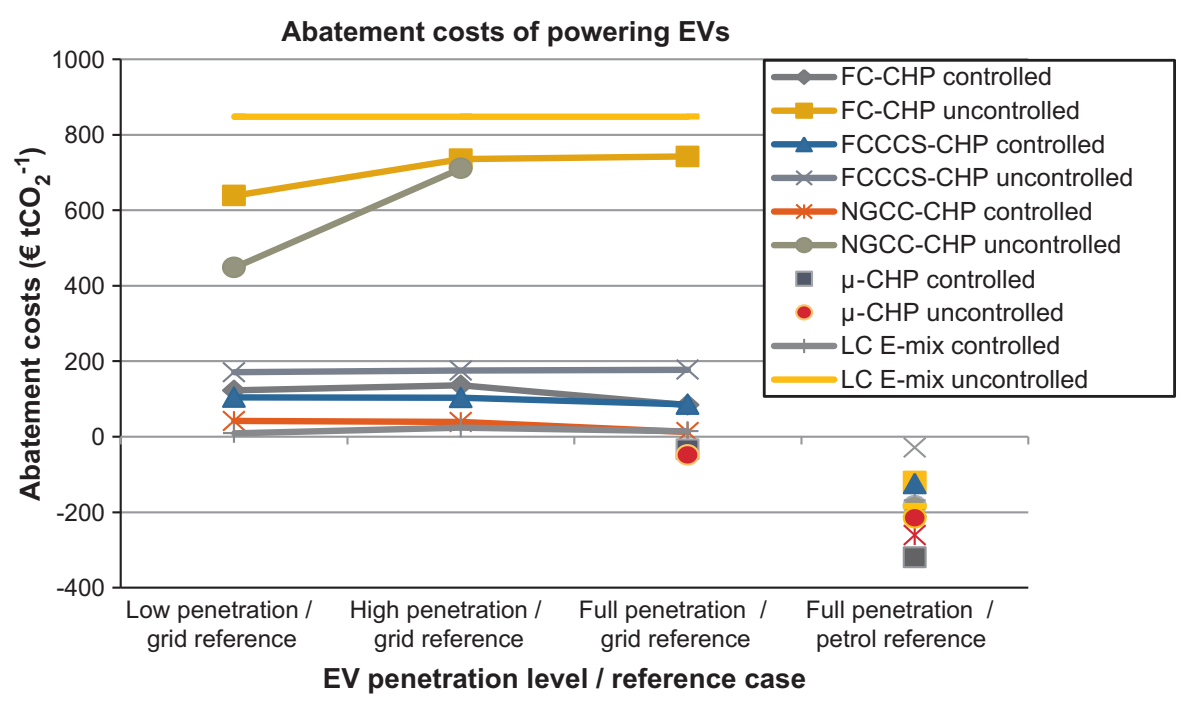

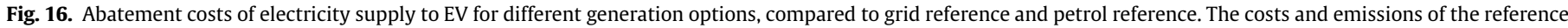
petrol vehicle have been corrected for the lower TTW efficiency compared to an EV.

tricity production cannot even meet all household electricity demand, and therefore only supplies little electricity to the EV.

Abatement costs do not differ much between different penetration levels of EVs, as shown in Fig. 16. Again, a clear distinction can be made between controlled and uncontrolled charging. In the controlled charging cases cheaper coal-fired grid electricity is used to power EVs rather than relatively expensive CHP-generated power, which decreases the overall costs of imports from the grid, but increases their emissions. The overall electricity costs for the EV decrease as a result, while the emissions increase. As the decrease in costs is stronger, the abatement costs become smaller as compared to the uncontrolled charging case. At the same time, the abatement potential also becomes smaller. The low-carbon electricity mix is an exception to this explanation: for uncontrolled charging is it largely powered by expensive natural gas capacity, but during controlled charging it is powered by coal fired power plants with CCS.

The micro-CHP options appear to be economically attractive with negative abatement costs, but their abatement potential is very limited. Only $4 \%$ of the EV electricity demand is fulfilled by the micro-CHP, the rest is imported from the grid and is as such totally almost identical to the reference case.

The abatement costs of powering a vehicle with electricity as compared to doing so with petrol are promising (Fig. 16). They clearly point out the strong point of EVs: that they can be powered more cheaply and that their $\mathrm{CO}_{2}$ emissions are lower compared to conventional cars. However, energy costs represent only one component of the Total Cost of Ownership, which is treated in the discussion section.

\subsection{Sensitivity analysis}

A sensitivity analysis was performed to check the robustness of the results, as specified in Table 11 . Results are shown for full (100\%) penetration because the results are more pronounced at higher penetration levels. The effects of changes in parameters have shown to be similar between controlled and uncontrolled charging. Results are only shown for controlled charging because its abatement costs are lower.

The sensitivity of the abatement costs of the combined household and EV to changes in input parameters are shown in Fig. 17. The figures show that comparable trends can be observed between
Table 11

Sensitivity analysis variations

\begin{tabular}{lll}
\hline Parameter & $\begin{array}{l}\text { Range (of } \\
\text { nominal } \\
\text { value) }\end{array}$ & Explanation for range \\
\hline $\begin{array}{l}\text { Household heat } \\
\text { demand }\end{array}$ & $-20 \%$, & $\begin{array}{l}\text { Heat demand in the build } \\
\text { environment could decrease } \\
\text { significantly in the future [86] }\end{array}$ \\
$\begin{array}{l}\text { Energy prices } \\
\text { Efficiency heat grid }\end{array}$ & $+50 \%$ & $\begin{array}{l}\text { Uncertainty in future energy prices } \\
\text { Heat losses may be lower when heat } \\
\text { demand is concentrated, e.g. in large } \\
\text { apartment blocks }\end{array}$ \\
$\begin{array}{l}\text { Efficiency CHP } \\
\text { Reimbursement for } \\
\text { electricity deliveries } \\
\text { to the grid }\end{array}$ & $\begin{array}{l} \pm 10 \% \\
\text { Range in Table } 4\end{array}$ \\
\hline
\end{tabular}

the FC-CHP, FCCCS-CHP and NGCC-CHP options. A reduced heat demand, lower CHP efficiency or reduced reimbursement for grid deliveries increases the abatement cost, while a higher efficiency of the CHP or the heat grid decreases it. For the FC-CHP and NGCC-CHP the changes are more pronounced, because their costs and emissions are closer to those of the reference situation. Variations in absolute costs in emissions will therefore have a stronger effect for these cases. A decrease in heat demand and improved heat grid efficiency have the strongest effects on the CHP cases, which marks the importance of heat deliveries for their business cases.

The abatement costs of the LC E-mix are not affected by changes in CHP-related parameters. They are affected by fuel prices: these change the merit order of the generators, which can have substantial effects.

The sensitivity of the abatement costs of powering just the EV are shown in Fig. 18. Most of the trends are comparable to those seen for the household plus EV, but there are differences.

The effect of a reduced heat demand is the main difference: it decreases rather than increases the abatement costs, as a result of the calculated electricity supply cost. Limited CHP-electricity is available for the EV, as less is generated. Instead, grid electricity is used that draws the abatement costs to the level of the grid-powered reference case at $€ 0$ per tonne. Furthermore, the effect of a change in 

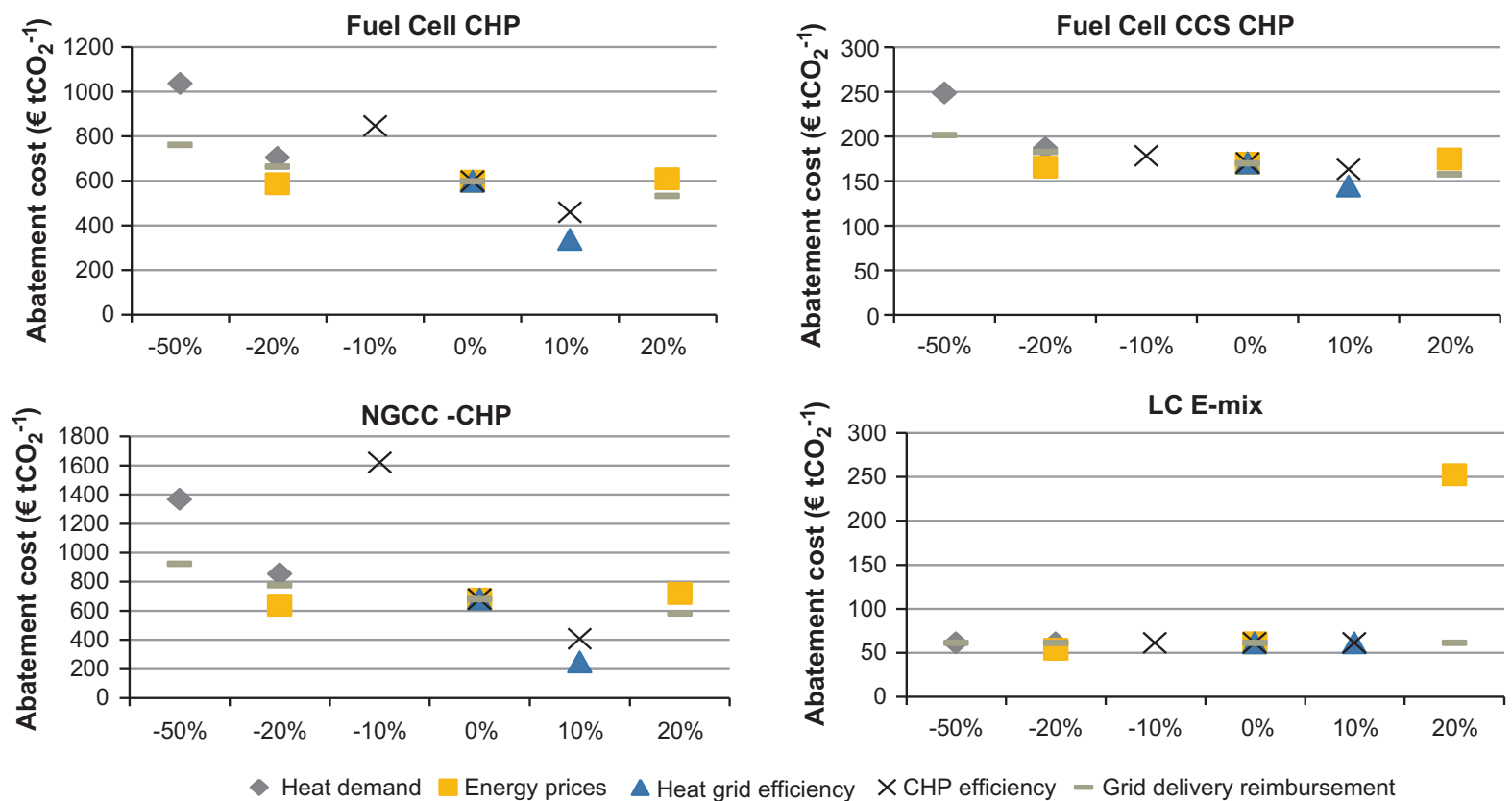

Fig. 17. Sensitivity of abatement cost for powering the household and EV. Deviation from input variable is displayed on the $x$-axis.

the reimbursement for electricity deliveries from the CHP to the grid is also somewhat stronger, especially for the NGCC-CHP.

\section{Discussion}

In this section, a number of limitations of the study are discussed, as well as some topics that can put the results in perspective. The main findings and key messages are presented in the conclusion.

\subsection{Impact of EV demand on cost and emission supply curves}

The effect of an increase in the number of EVs on the national power system is not included in this study. A substantial increase in the number of EVs will change the national electricity demand
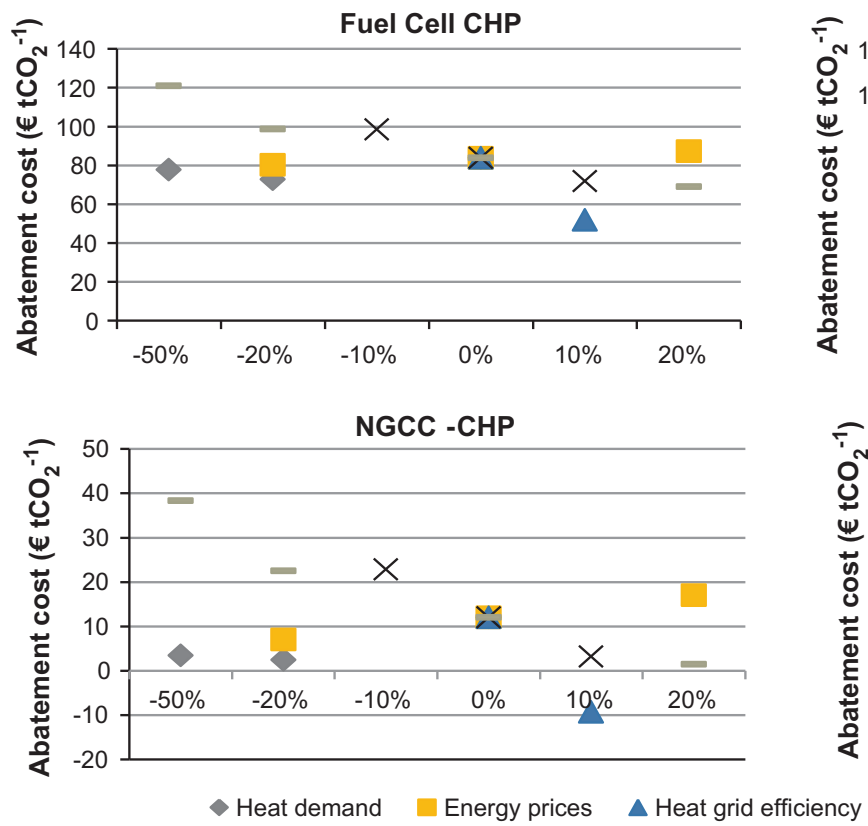

curves, on which the marginal cost and emission supply curves are based. Especially uncontrolled charging can aggravate the peak demand of the whole power system. The cost of powering an EV would increase as a result, while the emissions might increase or decrease, depending on the change in marginal generators.

In this study, the effect of extra CHP-installations on the national cost and emission curves is also not included, because the scope of this analysis is an area with just 50,000 households. Compared to the electricity supply and demand at a national scale, the effects of this area are negligible.

\subsection{Impact of merit order on the results}

The merit order of the power system is an important factor for this study's analyses. It affects the outcomes in two ways. The mar-
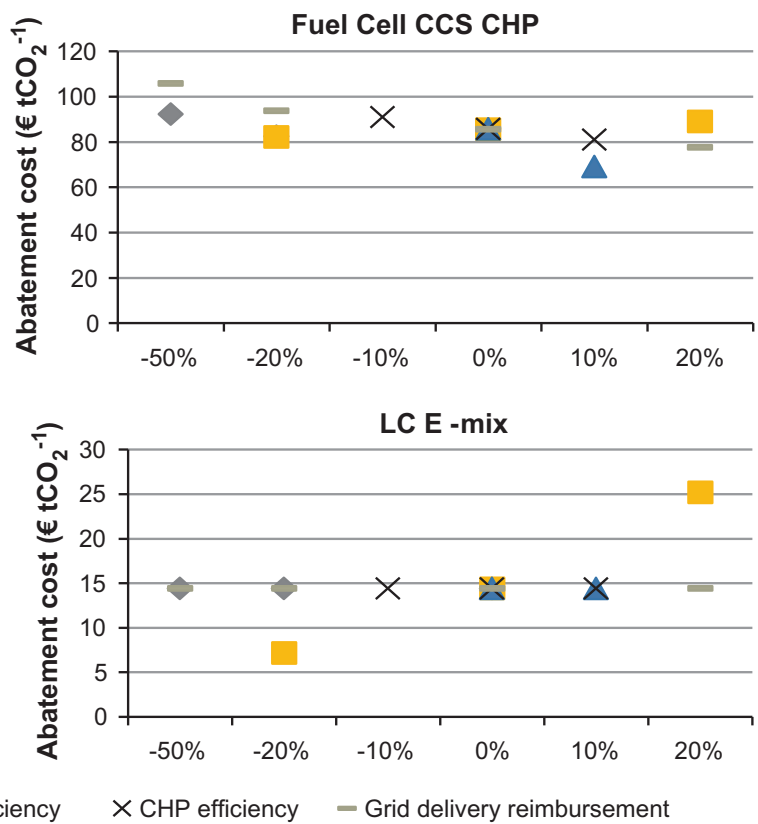

Fig. 18. Sensitivity of abatement cost for powering just the EV. Deviation from input variable is displayed on the $x$-axis. 
ginal costs and emissions determine the costs and emissions of exchanges between CHP installations and the grid. Secondly, the marginal costs and emissions form the basis of the reference cases, on which the abatement costs are based. A change of the marginal generators caused by a different merit order can therefore significantly alter the outcomes of this study.

The current scenarios produce results that are robust to some variation in energy and carbon prices, as shown by the effect of a change in demand in Figs. 6 and 7 and the sensitivity analysis. A major change in carbon price resulting from policy, or a decrease in coal-to-gas price ratio, for example resulting from the extraction of unconventional gas, could change the merit order in the future.

\subsection{Total cost of ownership of vehicles}

This study has only considered PHEVs, of which the energy costs have shown to be $20-80 \%$ lower than that of a petrol vehicle. The energy costs are only one component of the total cost of ownership of a car, however. They amount to about $18 \%$ of the total costs of ownership for the reference petrol vehicle, and 3-4\% of that of a future PHEV. The rest of the costs largely consist of the amortized purchase costs ( $75-80 \%$ for a PHEV and $60 \%$ for the petrol vehicle), and the maintenance costs $(17-18 \%$ for a PHEV, and $20 \%$ for the petrol vehicle). Overall, the total cost of ownership of a PHEV is projected to be $13-24 \%$ higher than that of an equivalent petrol vehicle [5].

The breakdown shows that the higher construction cost lead to the higher total cost of ownership. In particular the batteries are expensive. Their prices may decrease in the future, but only to a limited extent, so battery-costs will probably remain a substantial part of the construction cost of PHEVs [87]. It has been projected that PHEVs with a large battery (range $>100 \mathrm{~km}$ ), and BEVs will have a significantly higher (35-50\%) total cost of ownership because of their expensive battery pack $[7,88]$.

Other studies have looked at the total cost of ownership of a PHEV. Depending on assumptions of battery and energy prices and future tank-to-wheel efficiencies of cars, the total cost of ownership has been projected to be $15 \%$ [7] or $11 \%$ [89] higher than a conventional petrol vehicle. Only with a small battery (range of $<20 \mathrm{~km}$ ), PHEVs may have a lower total cost of ownership [88,90].

\subsection{Considerations about a district CHP infrastructure}

Considering the payback time and the nature of a heat grid, a district CHP system is a long term and inflexible investment. Although the CHP unit itself will be replaced after 15-20 years, the system as a whole has a much longer lifetime, and will not be able to adapt to changing conditions. The most important change would be the forecasted decrease in heat demand, which can occur abruptly when a whole neighborhood is renovated and fitted with better insulation. Not only will this decrease the load factor of the CHP units, it will also negatively impact the efficiency of the heat grid. ${ }^{12}$ Investments in new grids should therefore be carefully considered.

\subsection{Use of thermal storage to modify heat demand patterns}

The CHP electricity production pattern is defined by the household heat demand, which is highest between 6:00 and 12:00 and 16:00 and 23:00. The electricity demand of the household is more evenly distributed during the day, especially when EVs are charged in a controlled way. As a result, there are times that grid imports

\footnotetext{
12 When little heat is distributed to the grid, the absolute loss stays the same, but the relative loss is larger.
}

are needed, even if the household is a net exporter to the grid. Thermal storage could be used to improve the match between local electricity generation and supply, and perhaps result in future synergies between the CHP and EV.

\subsection{Use of EV batteries for electricity storage}

The electricity storage capacity of EV batteries could potentially result in synergies between EVs and CHP installations by storing CHP-generated electricity to sell it later at a higher price. This mechanism was not included in the model because of two reasons. First of all, the spread between the cost of electricity during the day and at night is at most $12 \%$, which is smaller than the combined charge and discharge efficiency loss of about $14 \%$ [7]. Secondly, it is assumed in this study that EVs are charged at night and that they will drive during the day, which limits the opportunities for electricity storage [91]. Future studies could further explore this synergy-mechanism for systems with a larger spread in electricity prices, based on more detailed EV usage patterns.

\section{Summary and conclusion}

This study investigated how the electricity demand of households with electric vehicles can be met by a range of CHP installations under different EV charging patterns with low costs and low emissions, and whether synergies can be achieved when EVs and CHP installations are jointly implemented.

It was found that EVs can on average increase the electricity demand of households by up to $42 \%$ ( $\pm 9 \%$ ) of household demand. This demand occurs during specific hours of the day, depending on the EV charging pattern. District CHP installations can supply a large part (25-75\%) of the electricity demand of EVs, depending on the temporal patterns of both heat and electricity demand of the household and EV. Also, seasonal variation in heat demand has a large impact on the extent to which electricity demand can be met. The quantity of grid imports is not much affected by the CHP electricity production: the additional electricity generation of the fuel cell CHP cases as compared to the NGCC-CHP case is mainly exported to the grid.

The results show that a centralized low-carbon power system may be the best way to fulfill the electricity demand of households with EVs in the future. Although costs increase by $30 \%$, which is partly caused by a carbon price that is $€ 60 t \mathrm{tO}_{2}^{-1}$ higher, emissions are reduced by $25-60 \%$ as compared to the grid reference case. This corresponds to an abatement cost between 60-190€tCO${ }_{2}^{-1}$. The costs of the NGCC-CHP and FC-CHP options are relatively high compared to the emission reduction, leading to abatement costs of about $€ 940$ and $€ 580 t \mathrm{tCO}_{2}^{-1}$ respectively. The Micro-CHP produces relatively little electricity at an abatement cost of $215 €$ $t \mathrm{CO}_{2}^{-1}$ : it only covers the electricity demand of the household. Compared to the petrol reference case, all options emit at least $40 \%$ less $\mathrm{CO}_{2}$, mostly at equal or lower costs. Only the FC-CCS and FCCCS-CHP options are more expensive ways to power a vehicle. The FCCCS-CHP installation will also allow for the capture of emissions resulting from heating of houses. This results in negative emissions that are twice the size of the emissions of the grid reference case when an equivalent of reference household boiler emissions is allocated to heating. The costs of this option are relatively high (3.6-4.7 times the costs of the grid reference case), which result in abatement costs of about $€ 165 t \mathrm{CO}_{2}^{-1}$. All results are sensitive to changes in the merit order and the CHP options are sensitive to changes in CHP efficiency and a decrease of the heat demand. 
Table 12

Specification of district CHP installations.

\begin{tabular}{|c|c|c|c|c|c|c|c|}
\hline NGCC-CHP specifications & (1) 2010 & (6) 2010 & (8) 2010 & (15) 2020-2025 & (12) 2010 & & Model values \\
\hline Electrical efficiency & $41 \%$ & $44 \%$ & $35-55 \%$ & $38-43 \%$ & 43 & & $43 \%$ \\
\hline Total efficiency & $75 \%$ & $88 \%$ & $60-85 \%$ & $78-83 \%$ & 77 & & $80 \%$ \\
\hline Investment cost $(€ / \mathrm{kW})$ & 1200 & 773 & 1250 & 560 & 1140 & & $€ 850$ \\
\hline Scale $\left(\mathrm{MW}_{\mathrm{e}}\right)$ & 60 & 50 & 31 & 90 & 60 & & 90 \\
\hline O\&M $(€ / M W h) /(\%)^{a}$ & $€ 11.2$ & $€ 4.2$ & $0.8 \%$ & $4 \%$ & & & $€ 5$ \\
\hline FC-CHP specifications & $(2,4) 2030$ & (3) 2030 & (7) 2010 & (9) 2020 & (13) Long term & (14) 2050 & Model values \\
\hline Electrical efficiency & $49-56 \%$ & $45-60 \%$ & $30-63 \%$ & $49-51 \%$ & $42 \%$ & $40-58 \%$ & $52 \%$ \\
\hline Total efficiency & $85-90 \%$ & $\mathrm{n} / \mathrm{a}$ & $65-80 \%$ & $72-75 \%$ & $82 \%$ & $80-85 \%$ & $85 \%$ \\
\hline Investment cost $(€ / \mathrm{kW})$ & target:1000-1250 & target: 522 & $2350-4600$ & target:1150-1300 & $€ 1600$ & $2320-3300$ & $€ \mathbf{1 7 5 0}$ \\
\hline Scale $\left(\mathrm{MW}_{\mathrm{e}}\right)$ & $0.25-5$ & $\mathrm{n} / \mathrm{a}$ & $0.01-2$ & $0.25-2$ & 5 & $0.2-2.5$ & $0.25-2$ \\
\hline O\&M $(€ / M W h) /(\%)^{a}$ & $2-5 \%$ & $€ 3-7$ & $€ 4-€ 35$ & $€ 10-€ 15$ & $5 \%$ & $€ 20-€ 25$ & $€ 15$ \\
\hline FCCCS-CHP specifications & SOFC (10) 2020 & SOFC-GT (11) 2030 & SOFC (13) Long term & & & & Model values \\
\hline Electrical efficiency & $47 \%$ & $59 \%$ & $40 \%$ & & & & $49 \%$ \\
\hline Total efficiency & $82 \%$ & $0 \%$ & $78 \%$ & & & & $77 \%$ \\
\hline Investment cost $(€ / \mathrm{kW})$ & target:2000 & Target: 1530 & $€ 2100$ & & & & $€ \mathbf{2 5 0 0}$ \\
\hline Scale $\left(\mathrm{MW}_{\mathrm{e}}\right)$ & 0.47 & 20 & 5 & & & & 20 \\
\hline O\&M $(€ / M W h) /(\%)^{\mathrm{a}}$ & $\mathrm{n} / \mathrm{a}$ & $3 \%$ & $5 \%$ & & & & $€ 21$ \\
\hline $\mathrm{CO}_{2}$ capture rate & $100 \%$ & $\sim 90 \%$ & $99 \%$ & & & & $99 \%$ \\
\hline
\end{tabular}

Sources: [48] (1), [53](2), [54] (3), [55] (4), [92] (5), [49] (6), [93] (7), [50] (8), [94] (9), [58] (10), [59] (11), [51] (12), [57] (13), [56] (14), [52] (15).

a $\mathrm{O} \& \mathrm{M}$ costs can either be expressed in a cost per MW h, or yearly sum as a percentage of the investment cost.

Next, the EV electricity demand and the CHP electricity supply that is available after fulfilling household demand were specifically studied to identify potential synergies. If synergies would occur, one would expect the abatement costs of EVs to drop at higher penetration rates. This was not observed, however: they remain at the same level between different penetration levels. It was observed that when charging in a controlled way, the EV electricity demand does not coincide well with CHP electricity production, though. Only $20-30 \%$ of EV demand will be delivered by the CHP at a $100 \% \mathrm{EV}$ penetration. The share of CHP electricity for uncontrolled charging is double of that: $55-65 \%$ at $100 \%$ EV penetration. At a household level, electricity is exported to the grid for all of these cases, so heat storage could be an option to improve the match in electricity supply and demand.

Overall, power generation with CHPs may be an inflexible investment that does not supply electricity to EVs at the lowest abatement costs in the long time future. Therefore, implementation should be carefully considered. One important obstacle is the mismatch in heat-driven electricity generation by CHP units and electricity demand of EVs. Low-carbon, centralized generation may be a better and more robust choice to power electric vehicles in the future. When electric vehicles are mainly powered by grid energy, the merit order is an important factor for the costs and emissions of transportation.

Recommended topics for further investigation would include:

- The effect of adding heat storage to a CHP system to improve the match between electricity demand and local supply.

- A power system study with a number of low-carbon electricity mix scenarios to further investigate the costs and emissions of powering EVs with grid electricity.

\section{Acknowledgements}

The authors would like to thank Oscar van Vliet (IIASA), Wouter Wetzels (ECN), Petra de Boer (KEMA) and Bart in 't Groen (KEMA) for their contributions to the study.

\section{Appendix A}

\section{A.1. Methodology to determine costs and emissions of centralized electricity generation}

\section{A.1.1. Cost and emissions of electricity generated by a centralized power plant}

To provide a reference framework, the costs and emissions of electricity generation by large centralized power plants were calculated using equations a1, a2, and a3. Inputs of these formulas are the investment cost, the operation and maintenance costs, and the efficiency of the power plant. The fuel costs were calculated directly from the efficiency of the power plant. ${ }^{13}$

Coe $=\frac{\alpha * I+O M+F}{E}$

where Coe is the cost of electricity $\left(€ \mathrm{~kW} \mathrm{~h}^{-1}\right), \alpha$ the capital recovery factor $\left(\mathrm{yr}^{-1}\right), I$ the initial investment $(€), \mathrm{OM}$ the annual costs for operation and maintenance $\left(€ \mathrm{yr}^{-1}\right), F$ the annual fuel costs $(€$ $\left.\mathrm{yr}^{-1}\right)$, and $E$ is the annual electricity production $\left(\mathrm{kW} \mathrm{h} \mathrm{yr}^{-1}\right)$

$\alpha=\frac{r}{1-(1+r)^{-l}}$

where $\alpha$ is the capital recovery factor $\left(\mathrm{yr}^{-1}\right), r$ the discount rate, and $l$ is the lifetime of the project $(\mathrm{yr})$

eoe $e_{\text {centralized }}=e_{\text {fuel }} * \frac{\frac{3.6}{\eta}}{1000}$

where $e o e_{\text {centralized }}$ is the emissions of electricity $\left(\mathrm{kg} \mathrm{CO}_{2} \mathrm{~kW} \mathrm{~h}^{-1}\right)$, $e_{\text {fuel }}$ the emissions of fuel type $\left(\mathrm{kg} \mathrm{CO}_{2} \mathrm{GJ}^{-1}\right), \eta$ is the efficiency power plant

\section{Appendix B}

See Table 12.

\footnotetext{
${ }^{13}$ Fuel cost $[€ / \mathrm{a}]=\left(\text { annual electricity production }[\mathrm{kWh} / \mathrm{a}] / \eta_{\text {electric }}\right)^{*}$ fuel price $[€ / \mathrm{kWh}]$.
} 


\section{B.1. Selection of future techno-economic parameters of CHP installations}

The parameters used in the analysis are based on values reported in literature, of which an overview is given in the table above. The selected parameters are mainly based on sources that provide long-term forecasts of the techno-economic parameters. The present day performance characteristics serve as a reference framework to evaluate the forecasts.

Based on present day gas turbine efficiencies, the efficiencies by Kuramochi seem relatively low. Therefore, the model values are based on the prognosis by the IEA. The NGCC model values are based on the high end values by Kuramochi, which are a couple of percentage points higher than the present day efficiencies. Forecasts on fuel cell specifications show a large spread. Relatively ambitious efficiencies are assumed for modeling, based on predictions of the IEA. A performance penalty of $8 \%$-points (3\% electricity, $5 \%$ heat) is considered for the fuel cell installation with CCS as compared to the one without. This penalty is based on the results by Kuramochi.

\section{References}

[1] OECD/IEA. CO2 emissions from fuel combustion. IEA: Paris; 2011. p. 134.

[2] CIT. Transport and climate change. Commision for intergrated transport; 2007. p. 21.

[3] EPA. Inventory of U.S. Greenhouse Gas Emissions and Sinks 1990-2009. U.S. Environmental Protection Agency; 2011.

[4] Hanschke CB et al. Duurzame innovatie in het wegverkeer. ECN: Petten; 2009.

[5] van Vliet $O$ et al. Techno-economic comparison of series hybrid, plug-in hybrid, fuel cell and regular cars. J Power Sources 2010;195(19):6570-85.

[6] Campanari S, Manzolini G, Garcia de la Iglesia F. Energy analysis of electric vehicles using batteries or fuel cells through well-to-wheel driving cycle simulations. J Power Sources 2009;186(2):464-77.

[7] Vliet OV et al. Energy use, cost and $\mathrm{CO} 2$ emissions of electric cars. J Power Sources 2011;196(4)

[8] OECD/IEA. Technology roadmap - electric and plug-in hybrid electric vehicles. Paris: International Energy Agency; 2011

[9] WDI. Actieplan decentrale infrastructuur. Werkgroep Decentrale Infrastructuur, SenterNovem: Utrecht; 2008. p. 16.

[10] Johansson $\mathrm{B}$, Mårtensson $\mathrm{A}$. Energy and environmental costs for electric vehicles using CO2-neutral electricity in Sweden. Energy 2000;25(8):777-92.

[11] Parks K, Denholm P, Markel T. Costs and emissions associated with plug-in hybrid electric vehicle charging in the Xcel energy Colorado service territory. U.S. National Renewable Energy Laboratory; 2007.

[12] Shinoda Y et al. Evaluation of the plug-in hybrid electric vehicle considering power generation best mix. IEEJ Trans Power Energy 2008;128(6):827-35.

[13] Kintner-Meyer M, Schneider K, Pratt R. Impacts assessment of plug-in hybrid vehicle on electric utilities and regional U.S. power grids. Pacific Northwest National Laboratory; 2007.

[14] Smith WJ. Plug-in hybrid electric vehicles-a low-carbon solution for Ireland? Energy Policy 2004;38(3):1485-99.

[15] Baptista P, Tomás M, Silva C. Plug-in hybrid fuel cell vehicles market penetration scenarios. Int J Hydrogen Energy 2010;35(18):10024-30.

[16] EP. Directive on the promotion of cogeneration based on a useful heat demand in the internal energy market. In: COM 2004/8/EC, European Parliament, Editor; 2004.

[17] OECD/IEA. Combined heat \& power and emissions trading - options for policy makers. International Energy Agency: Paris; 2008c.

[18] Lund H, Kempton W. Integration of renewable energy into the transport and electricity sectors through V2G. Energy Policy 2008;36(9):3578-87.

[19] Blarke MB, Lund $H$. The effectiveness of storage and relocation options in renewable energy systems. Renewable Energy 2008;33(7):1499-507.

[20] Momber I. Plug-in electric vehicle interactions with a small office building: an economic analysis using DER-CAM. Lawrence Berkeley National Laboratory; 2010.

[21] Acha S, Green TC, Shah N. Effects of optimised plug-in hybrid vehicle charging strategies on electric distribution network losses. In: IEEE PESTransmission and distribution conference and exposition. New Orleans; 2010.

[22] van den Broek M et al. Impact of international climate policies on $\mathrm{CO} 2$ capture and storage deployment: Illustrated in the Dutch energy system. Energy Policy 2011;39(4):2000-19.

[23] Hawkes A, Leach M. Impacts of temporal precision in optimisation modelling of micro-Combined Heat and Power. Energy 2005;30(10):1759-79.

[24] Broek Mvd, Faaij APC, Turkenburg WC. Planning for an electricity sector with carbon capture and storage: case of the Netherlands. Int J Greenhouse Gas Control 2008;2(1):25.
[25] Benz $E$ et al. Integratie van windenergie in het Nederlandse elektriciteitsysteem in de context van de Noordwest Europese elektriciteitmarkt. KEMA: Arnhem; 2010.

[26] Faber A, Ros JPM. Decentrale elektriciteitsvoorziening in de gebouwde omgeving. Evaluatie op basis van systeemtransities. Planbureau voor de Leefomgeving: Bilthoven; 2009.

[27] Uitzinger J. SEPATH, Simulatie van EnergievraagPATronen van Huishoudens.IVAM: Amsterdam; 2003. p. 90.

[28] Turkstra JW. Beschrijving van de TREIN profielgenerator voor gas en elektriciteit. KEMA: Arnhem; 2009.

[29] SenterNovem, Eindrapport TREIN-deel 1 (Transitie Roadmap Energie Infrastructuur in Nederland). SenterNovem; 2009.

[30] Hawkes AD, Leach MA. Cost-effective operating strategy for residential microcombined heat and power. Energy 2007;32(5):711-23.

[31] OECD/IEA. Projected Costs of Generating Electricity. Paris: IEA; 2010c.

[32] OECD/IEA. Methodology for calculating electricity and heat marginal abatement cost curves (MACC) in the IEA World Energy Outlook 2009. IEA: Paris; 2009c.

[33] Reserve, U.S.F. Foreign Exchange Rates - H.10; 2012 . <http:// www.federalreserve.gov/releases/h10/hist/dat00_eu.htm> [cited 12.04.12].

[34] OECD/IEA. World Energy Outlook 2011. Paris: IEA; 2011.

[35] OECD/IEA. World Energy Outlook 2010. Paris: International Energy Agency; 2010.

[36] Blok K. Introduction to energy analysis. Amsterdam: Techne Press; 2007.

[37] EIA. Gasoline and diesel fuel update; 2011. <http://www.eia.gov/oog/info/gdu/ gasdiesel.asp> [cited 18.09.11]

[38] Vaessen P. Electricity grid losses. Arnhem; 2010.

[39] De Jong A, et al. Energie-en CO2-besparingspotentieel van micro-wkk in Nederland (2010-2030). Platform Nieuw Gas; 2008.

[40] Bosselaar L, Gerlagh T. Protocol monitoring duurzame energy, update 2006. SenterNovem: Sittard, The Netherlands; 2006.

[41] Eurostat. Motorisation rate. Eurostat; 2011.

[42] UNECE. Trends in Europe and North America. United Nations Economic Comission for Europe; 2003.

[43] Chatterjee K, Gordon A. Planning for an unpredictable future: transport in Great Britain in 2030. Transp Policy 2006;13(3):254-64.

[44] Janssen LHJM, Okker VR, Schuur J. Welvaart en Leefomgeving. Gezamelijke planbureau's; 2006.

[45] Petrill EM. Comments from EPRI on California public utilities commission staff's white paper, light-duty vehicle electrification in California: potential barriers and opportunities. EPRI: Palo Alto; 2009.

[46] Foley A et al. Impacts of Electric Vehicle charging under electricity market operations. Appl Energy 2013;101:93-102.

[47] Daniëls B, Kruitwagen S. Referentieraming energie en emissies 20102020. Petten: ECN and PBL; 2010.

[48] Hers JS et al. Onrendabele top berekeningen voor nieuw WKK-vermogen 2008. Energie Onderzoekcentrum Nederland: Petten; 2008.

[49] Joelsson A, Gustavsson L. District heating and energy efficiency in detached houses of differing size and construction. Appl Energy 2009;86(2):126-34.

[50] Lazzarin R, Noro M. Local or district heating by natural gas: which is better from energetic, environmental and economic point of views? Appl Therm Eng 2006;26:244-50.

[51] Jacobs Consultancy. Techno-Economische Parameters MEP/SDE WKK 2008 Jacobs Consultancy: Leiden; 2008.

[52] Kuramochi T et al. Prospects for cost-effective post-combustion CO2 capture from industrial CHPs. Int J Greenhouse Gas Control 2010;4(3):511-24.

[53] Krewitt W, Schmid S. Fuel cell technologies and hydrogen production/ distribution options. Cologne: German Aerospace Center; 2005.

[54] Halliday J et al. Fuel cells: providing heat and power in the urban environment. Tyndall Centre: Norwich; 2005.

[55] Krewitt W et al. Market perspectives of stationary fuel cells in a sustainable energy supply system-long-term scenarios for Germany. Energy Policy 2006;34(7):793-803.

[56] OECD/IEA. Energy technology perspectives. International Energy Agency: Paris; 2010b.

[57] Kuramochi T, Turkenburg W, Faaij A. Competitiveness of $\mathrm{CO} 2$ capture from an industrial solid oxide fuel cell combined heat and power system in the early stage of market introduction. Fuel 2011;90(3):958-73.

[58] Hendriks C, et al. CO2 capture from medium scale combustion installations. IEA Greenhouse Gas R \& D Programme: Cheltenham; 2007.

[59] Damen K, Faaij A, Turkenburg W. Pathways towards large-scale implementation of $\mathrm{CO} 2$ capture and storage: a case study for the Netherlands. Int J Greenhouse Gas Control 2009;3(2):20.

[60] Schepers BL, Valkengoed MPJv. Warmtenetten in Nederland - Overzicht van grootschalige en kleinschalige warmtenetten in Nederland. CE Delft: Delft; 2009. p. 76.

[61] Overdiep HG, Assink Arnold Peter, Overmars Pieternel. Warmte en kracht: WarmteKrachtKoppeling: een overzicht en leidraad. Groningen: Castel International Publishers; 2008.

[62] Melick MAJv, Weiden AGMvd. Warmteleveringsystemen voor Nederland. SenterNovem: Sittard; 2007.

[63] Harmelink M, Bosselaar L. Uniforme Maatlat voor de warmtevoorziening in de woningbouw. Sittard: SenterNovem; 2009.

[64] Consonni S, Giugliano M, Grosso M. Alternative strategies for energy recovery from municipal solid waste: Part B: Emission and cost estimates. Waste Manage (Oxford) 2005;25(2):137-48. 
[65] Leeuwen CWv, Timmerman P. Haalbaarheidsstudie warmtenet Stadsgewest Haaglanden. Gemeente Rotterdam: Rotterdam; 2008.

[66] Späth P. District heating and passive houses - interfering strategies towards sustainable energy systems. In: 4S/EASST conference2004, Graz university research centre for technology, work and culture: Paris.

[67] Bongaerts M. Dutch direction: integrating micro CHP into a smart electricity grid, in Cogeneration on-site power2007, PennWell International Publications Limited: Upshire.

[68] Loh HP, Lyons J. Process equipment cost estimation. Pittsburgh: National Energy Technology Center; 2002.

[69] Grahn M et al. Biomass for heat or as transportation fuel? A comparison between two model-based studies. Biomass Bioenergy 2007;31(1112):747-58

[70] ZEP. The costs of CO2 transport. Post-demonstration CCS in the EU. European technology platform for zero emission fossil fuel power plants: Brussels; 2011.

[71] ZEP. The Costs of CO2 Storage. Post-demonstration CCS in the EU. European technology platform for zero emission fossil fuel power plants: Brussels; 2011.

[72] Hlebnikov A, Siirde A, Paist A. The Estonian district heating networks major characteristic parameters difference from the optimal values and efficiency increasing potential. In: Topical problems in the field of electrical and power engineering. Kuressaare, Estonia; 2008.

[73] Meenen Rv. Performance of piping systems used in district heating distribution networks in the Netherlands during the last 40 years. BGP Engineers: Uden; 2010.

[74] Casisi M, Pinamonti P, Reini M. Optimal lay-out and operation of combined heat \& power (CHP) distributed generation systems. Energy 2009;34(12):2175-83.

[75] Bennink D, Benner JHB. Cost drivers warmtelevering in Nederland. Inzicht in de belangrijkste cost drivers van warmteleveranciers in Nederland. CE Delft: Delft; 2009. p. 39.

[76] Stevens P, editor. The economics of energy. Cheltenham: Edward Elgar; 2004.

[77] Wu DW, Wang RZ. Combined cooling, heating and power: a review. Prog Energy Combust Sci 2006;32(5-6):459-95.

[78] Faaij, Treffers, et al. Database on clean energy supply 2050. Utrecht Center for Energy Research: Utrecht; 2001

[79] Simader G, Krawinkler R, Trnka G. Micro CHP systems:state-of-theart. Vienna: Austrian Energy Agency; 2006.
[80] Onovwiona HI, Ugursal VI. Residential cogeneration systems: review of the current technology. Renew Sustain Energy Rev 2006;10(5):389-431.

[81] Damen $\mathrm{K}$ et al. A comparison of electricity and hydrogen production systems with $\mathrm{CO} 2$ capture and storage-Part B: Chain analysis of promising CCS options. Prog Energy Combust Sci 2007;33(6):580-609.

[82] Weiss $M$ et al. Market diffusion, technological learning, and cost-benefit dynamics of condensing gas boilers in the Netherlands. Energy Policy 2009;37(8):15.

[83] EC, European Energy and Transport - Trends to 2030-2007 update. European Commission Directorate-General for Energy and Transport: Luxembourg; 2008.

[84] Tenne T. Database of daily electricity use on 15 minute interval. TenneT; 2009.

[85] Damen K et al. A comparison of electricity and hydrogen production systems with $\mathrm{CO} 2$ capture and storage. Part A: Review and selection of promising conversion and capture technologies. Prog Energy Combust Sci 2006;32(2):215-46.

[86] Jong A et al. De Autarke Wijk. Cogen Projects: Driebergen; 2008.

[87] Gerssen-Gondelach SJ, Faaij APC. Performance of batteries for electric vehicles on short and longer term. J Power Sources 2012;212:111-29.

[88] Shiau C-SN et al. Impact of battery weight and charging patterns on the economic and environmental benefits of plug-in hybrid vehicles. Energy Policy 2009;37(7):2653-63.

[89] Douglas C, Stewart A. Influences on the Low Carbon Car Market from 20202030. Cambridge: Element Energy; 2011.

[90] Ernst C-S et al. Battery sizing for serial plug-in hybrid electric vehicles: A model-based economic analysis for Germany. Energy Policy 2011;39(10):5871-82.

[91] Kristoffersen TK, Capion K, Meibom P. Optimal charging of electric drive vehicles in a market environment. Appl Energy 2011;88(5):1940-8.

[92] Harvey S, Carcasci C, Berntsson T. Gas turbines in district heating combined heat and power systems: influence of performance on heating costs and emissions. Appl Therm Eng 2000;20(12):1075-103.

[93] EPA. Catalogue of CHP Technologies. Environmental Protection Agency: Washington D.C; 2002.

[94] Hawkins S, Joffe D, Hughes N. Hydrogen fuel cells for stationary power: technological characterisation and market assessment. Westminster: University of Westminster; 2005. 